Prepared in cooperation with the

Massachusetts Department of Fish and Game, Division of Ecological Restoration

\title{
Estimated Sediment Thickness, Quality, and Toxicity to Benthic Organisms in Selected Impoundments in Massachusetts
}

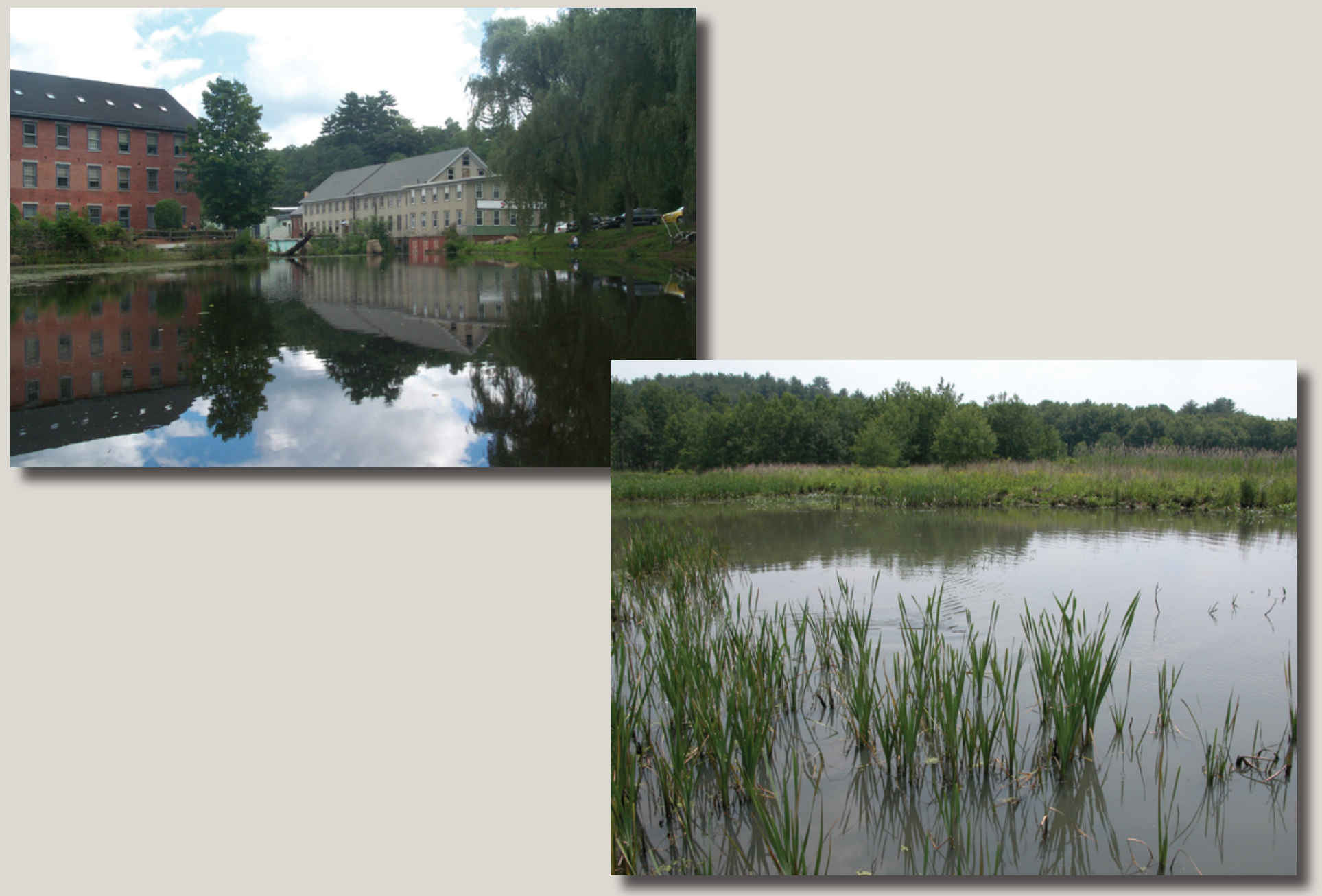

Scientific Investigations Report 2012-5191 
Cover. Upper Left-The Ballardville impoundment on the Shawsheen River, Andover, Massachusetts.

Lower Right—Rice City impoundment on the Blackstone River, Uxbridge, Massachusetts. Photographs by Robert F. Breault. 


\section{Estimated Sediment Thickness, Quality, and Toxicity to Benthic Organisms in Selected Impoundments in Massachusetts}

By Robert F. Breault, Jason R. Sorenson, and Peter K. Weiskel

Prepared in cooperation with the

Massachusetts Department of Fish and Game, Division of Ecological Restoration

Scientific Investigations Report 2012-5191 


\section{U.S. Department of the Interior \\ KEN SALAZAR, Secretary \\ U.S. Geological Survey \\ Marcia K. McNutt, Director}

U.S. Geological Survey, Reston, Virginia: 2013

For more information on the USGS - the Federal source for science about the Earth, its natural and living resources, natural hazards, and the environment, visit http://www.usgs.gov or call 1-888-ASK-USGS.

For an overview of USGS information products, including maps, imagery, and publications, visit http://www.usgs.gov/pubprod

To order this and other USGS information products, visit http://store.usgs.gov

Any use of trade, firm, or product names is for descriptive purposes only and does not imply endorsement by the U.S. Government.

Although this information product, for the most part, is in the public domain, it also may contain copyrighted materials as noted in the text. Permission to reproduce copyrighted items must be secured from the copyright owner.

Suggested citation:

Breault, R.F., Sorenson, J.R., and Weiskel, P.K., 2013, Estimated sediment thickness, quality, and toxicity to benthic organisms in selected impoundments in Massachusetts: U.S. Geological Survey Scientific Investigations Report 2012-5191, 42 p., at http://pubs.usgs.gov/sir/2012/5191/. 


\section{Acknowledgments}

The authors wish to express their gratitude to the Massachusetts Department of Fish and Game, Division of Ecological Restoration (DFG/DER) for their support of this study. We would particularly like to thank Tim Purinton, Eileen Goldberg, Beth Lambert, Alex Hackman, and Chris Leuchtenburg for their assistance throughout. The cooperation of public and private landowners who granted permission to access the impoundments also is appreciated.

The authors thank Leslie DeSimone and Jonathan Morrison of the U.S. Geological Survey (USGS), and Alex Hackman of the DFG/DER for their technical reviews of the report and Andrew Massey and Dave Armstrong of the USGS for their field and modeling assistance. The authors also thank Lance Ostiguy and Pete Steeves of the USGS for their geographic information systems assistance, Anna Glover of the USGS for editorial review, and Susan Bergin, Ann Marie Squillacci, and others in the USGS Pembroke Publishing Service Center for their work on the figures, tables, and layout of the report. 
THIS PAGE INTENTIONALLY LEFT BLANK 


\section{Contents}

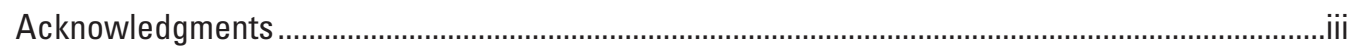

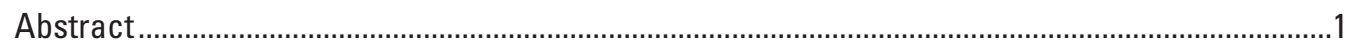

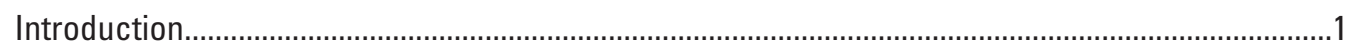

Purpose and Scope ......................................................................................................

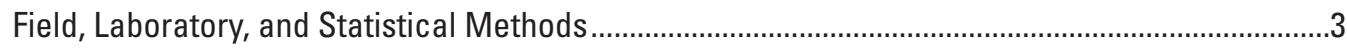

Site Selection and Sampling Techniques ............................................................................

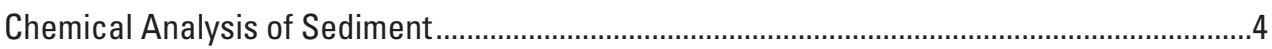

Analysis of Inorganic Elements .................................................................................

Organic Analysis ......................................................................................................

Bias and Variability in Field and Laboratory Analyses ....................................................

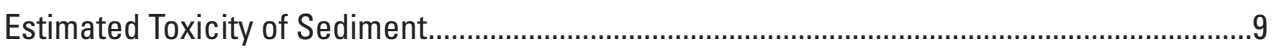

Sediment Thickness, Chemical Quality, and Estimated Toxicity .................................................10

Measured Sediment Thicknesses and Estimated Volumes....................................................10

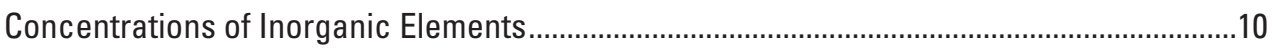

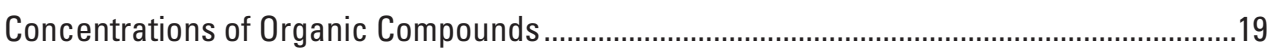

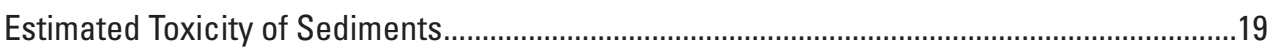

Relations Among Contaminant Concentrations, Land Use, and Industrial History ..........................25

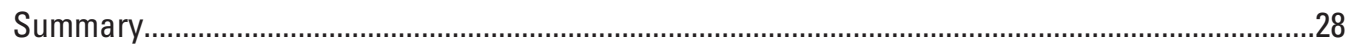

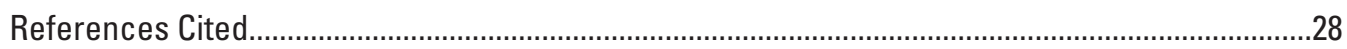

\section{Figures}

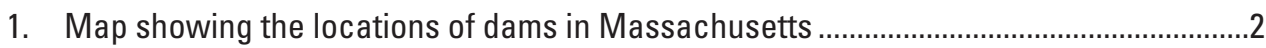

2. Map showing locations of impoundments in Massachusetts assessed in this study and the drainage areas to the dams that form the impoundments ...................................

3. Photographs showing measurement of soft-sediment thickness where $A$, dam has been breached and the impoundment has been drained and $B$, impoundment is present at the time of sampling .....................................................................................

4. Photographs showing methods used to obtain cores from impoundments ......................7

5. Photographs showing examples of core penetration through the full thickness of impounded sediment into preimpoundment material......................................................8

6. Graphs showing concentrations of $A$, arsenic, $B$, cadmium, $C$, chromium, $D$, copper, $E$, lead, $F$, nickel, and $G$, zinc in sediment samples from 32 impoundments in Massachusetts...

7. Graphs showing concentrations for $A$, total polycyclic aromatic hydrocarbons, $B$, total polychlorinated biphenyls, and $C$, total dichlorodiphenyl-trichloroethylene (DDT) compounds in sediment samples from 32 impoundments in Massachusetts.......20 


\section{Tables}

1. Characteristics of selected dams in Massachusetts and sampling information for 2004 and 2005.

2. Bottom-sediment thicknesses and estimated volumes of sampled impoundments in Massachusetts in 2004 and 2005.

3. Concentrations of inorganic elements measured in bottom-sediment cores collected from selected impoundments in Massachusetts in 2004 and 2005

4. Concentrations of organic compounds measured in bottom-sediment cores collected from selected impoundments in Massachusetts in 2004 and 2005.

5. Average probable effects concentration quotients for bottom-sediment cores collected from selected impoundments in Massachusetts in 2004 and 2005.

6. Likelihood of toxicity of bottom-sediment cores collected from selected impoundments in Massachusetts in 2004 and 2005

7. Land use characteristics of selected impoundment drainage areas in Massachusetts

8. Relations between sediment-core contaminant concentrations and land use in the drainage areas of selected impoundments in Massachusetts.

\section{Conversion Factors, Datum, and Abbreviations}

Inch/Pound to SI

\begin{tabular}{lll}
\hline \multicolumn{1}{c}{ Multiply } & By & \multicolumn{1}{c}{ To obtain } \\
\hline inch (in.) & Length & \\
foot (ft) & 2.54 & centimeter $(\mathrm{cm})$ \\
mile (mi) & 0.3048 & meter $(\mathrm{m})$ \\
\hline & 1.609 & kilometer $(\mathrm{km})$ \\
\hline square foot $\left(\mathrm{ft}^{2}\right)$ & Area & \\
square mile $\left(\mathrm{mi}^{2}\right)$ & 0.09290 & square meter $\left(\mathrm{m}^{2}\right)$ \\
& 2.590 & square kilometer $\left(\mathrm{km}^{2}\right)$ \\
\hline gallon $\left(\mathrm{gal}^{2}\right)$ & Volume & \\
cubic foot $\left(\mathrm{ft}^{3}\right)$ & 3.785 & liter $(\mathrm{L})$ \\
cubic yard $\left(\mathrm{yd}^{3}\right)$ & 0.02832 & cubic meter $\left(\mathrm{m}^{3}\right)$ \\
\hline & 0.7646 & cubic meter $\left(\mathrm{m}^{3}\right)$ \\
\hline ounce, avoirdupois $(\mathrm{oz})$ & Mass & \\
\hline
\end{tabular}

Temperature in degrees Celsius $\left({ }^{\circ} \mathrm{C}\right)$ may be converted to degrees Fahrenheit $\left({ }^{\circ} \mathrm{F}\right)$ as follows:

$$
{ }^{\circ} \mathrm{F}=\left(1.8 \times{ }^{\circ} \mathrm{C}\right)+32
$$

Vertical coordinate information is referenced to the North American Vertical Datum of 1988 (NAVD 88).

Horizontal coordinate information is referenced to the North American Datum of 1983 (NAD 83).

Concentrations of chemical constituents (inorganic elements and organic compounds) in bottom sediment are given in parts per million (ppm) and parts per billion (ppb). 


\section{Abbreviations}

$\begin{array}{ll}\text { AVS } & \text { acid-volatile sulfides } \\ \text { CIT } & \text { commercial, industrial, and transportation } \\ \text { DDE } & \text { dichlorodiphenyl-dichloroethylene } \\ \text { DDT } & \text { dichlorodiphenyl-trichloroethane } \\ \text { DO } & \text { dissolved oxygen } \\ \text { ODS } & \text { Office of Dam Safety } \\ \text { HRGC/LRMS } & \text { high-resolution gas chromatography/low-resolution mass spectrometry } \\ \text { ICP-MS } & \text { inductively coupled mass spectrometry } \\ \text { MDFG } & \text { Massachusetts Department of Fish and Game } \\ \text { MDER } & \text { Massachusetts Division of Ecological Restoration } \\ \text { NID } & \text { U.S. Army Corps of Engineers National Inventory of Dams } \\ \text { NIST } & \text { National Institute of Standards and Technology } \\ \text { NWOL } & \text { National Water Quality Laboratory } \\ \text { PAH } & \text { polycyclic aromatic hydrocarbon } \\ \text { PCB } & \text { polychlorinated biphenyl } \\ \text { PEC } & \text { probable effects concentration } \\ \text { PECQ } & \text { probable effects quotient for an individual contaminant in a sample } \\ \text { PECQ } & \text { average probable effects quotient for a sample } \\ \text { OA/OC } & \text { quality assurance/quality control } \\ \text { RPD } & \text { relative percent difference } \\ \text { SOD } & \text { sediment-oxygen demand } \\ \text { TEC } & \text { threshold effects concentration } \\ \text { USGS } & \text { U.S. Geological Survey } \\ \end{array}$


THIS PAGE INTENTIONALLY LEFT BLANK 


\title{
Estimated Sediment Thickness, Quality, and Toxicity to Benthic Organisms in Selected Impoundments in Massachusetts
}

\author{
By Robert F. Breault, Jason R. Sorenson, and Peter K. Weiskel
}

\section{Abstract}

There are presently more than 3,000 dams in Massachusetts. Many of these dams are no longer used for their original purpose, and some are in disrepair. Contaminants bound to sediment trapped behind dams have the potential to affect the downstream environment in the event of a sudden release or dam failure. These sediments may also be an ongoing source of contaminants to overlying water and to organisms living on or in bottom sediment. In addition, dams do not entirely retain impounded sediment and associated contaminants. Such sediments are subject to scour, resuspension, and downstream redistribution during storm events.

The U.S. Geological Survey and the Massachusetts Department of Fish and Game, Division of Ecological Restoration, collaborated to collect baseline information on the quantity and quality of sediment impounded behind selected dams in Massachusetts, including sediment thickness and the occurrence of contaminants potentially toxic to benthic organisms. The thicknesses of impounded sediments were measured, and cores of sediment were collected from 32 impoundments in 2004 and 2005. Cores were chemically analyzed, and concentrations of 32 inorganic elements and 108 organic compounds were quantified. Sediment thicknesses varied considerably among the 32 impoundments, with an average thickness of 3.7 feet. Estimated volumes also varied greatly, ranging from 100,000 cubic feet to 81 million cubic feet. Concentrations of toxic contaminants as well as the number of contaminants detected above analytical quantification levels (also known as laboratory reporting levels) varied greatly among sampling locations. Based on measured contaminant concentrations and comparison to published screening thresholds, bottom sediments were predicted to be toxic to bottom-dwelling (benthic) organisms in slightly under 30 percent of the impoundments sampled. Statistically significant relations were found between several of the contaminants and individual indicators of urban land use and industrial activity in the upstream drainage areas of the impoundments. However, models developed to estimate contaminant concentrations at unsampled sites from upstream landscape characteristics had low predictive power, consistent with the long and complex land-use history that is typical of many drainage areas in Massachusetts.

\section{Introduction}

More than 3,000 dams presently impound the streams of Massachusetts, according to the Division of Ecological Restoration of the Massachusetts Department of Fish and Game (MDER, written commun., 2013). Nearly 1,500 of these dams are also listed in the National Inventory of Dams (U.S. Army Corps of Engineers, 1996). Worcester County, in central Massachusetts, has more dams than any other county in the United States (425; Graf, 1999). Because many Massachusetts dams no longer serve their original purposes, may present safety risks, and have the potential to impair ecological conditions, public interest in removing unused dams has grown substantially in recent years. Dams not only restrict the recreational use of rivers for boaters, they also limit or block the free passage of fish and other biota, slow water velocities, cause sediment and organic matter to settle out, and commonly raise water temperatures. This combination of factors affects water quality, impairs in-stream habitat, alters food web dynamics, and limits access to different habitats for resident and migratory fish (Wang and others, 2010; Armstrong and others, 2011). Dam removal can increase the amount of suitable aquatic habitat in a stream system, both upstream and downstream of the original structure, as well as restore ecological processes (for example, the natural movement of water, sediment, and organic matter) that form and maintain downstream habitat and food web dynamics over time (Poff and Hart, 2002; Gardner and others, 2011).

The purposeful breaching and removal of dams can have unintended effects on the downstream environment if not thoughtfully planned and implemented. One potential negative effect is the release of toxic contaminants by mobilization, transport, and downstream redeposition of impounded sediment. Many contaminants discharged to rivers and streams in the form of industrial wastes, accidental spills, or urban runoff 


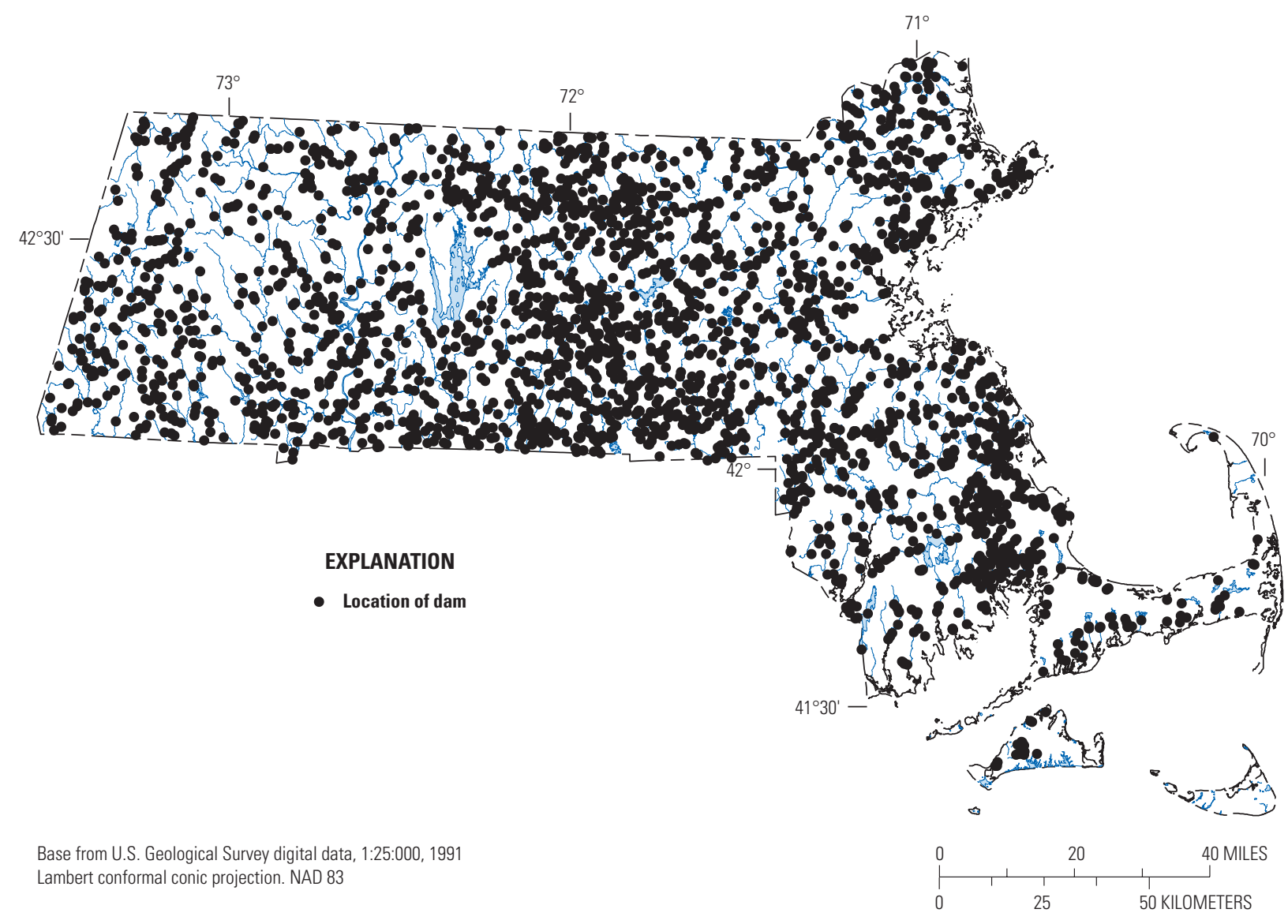

Figure 1. The locations of dams in Massachusetts. Data are from the U.S. Army Corps of Engineers (1996).

commonly adhere to solids suspended in the water column of a stream and ultimately accumulate in slack water environments, such as impoundments behind dams. The accumulation of contaminated sediments behind dams in Massachusetts began principally after 1810 , in the early years of the industrial revolution in the Commonwealth (Brown and Tager, 2000, p. 121). Urbanization in the latter part of the 19th century and throughout the 20th century further increased the load of contaminants from urban watershed sources to stream impoundments (see, for example, Breault and others, 2000, 2004, 2005).

Although contaminants trapped in sediment behind dams are often considered buried, it is incorrect to assume that these contaminants are immobile. For example, some contaminants are easily exchanged between bottom sediment and the overlying water column, allowing these contaminants to become biologically available under certain environmental conditions. Moreover, sediment-bound contaminants can be scoured, resuspended, transported downstream and redeposited during storm events, potentially affecting aquatic organisms, including fish, a long distance from the original source. Benthic organisms, which live on or within the bottom sediment, may be directly exposed to hazardous levels of these contaminants and, in turn, indirectly expose fish and other wildlife to the contaminants through food-web magnification. Humans may be exposed through ingestion of affected wildlife or by direct physical contact.

The Massachusetts Office of Dam Safety (ODS) requires regular safety inspections at dams under ODS jurisdiction. However, such inspections do not presently (2012) include estimates of the volume of impounded bottom sediment nor do they include the occurrence of potentially toxic contaminants trapped behind these dams. Hence, this aspect of the overall hazard associated with accidental dam failures or purposeful dam breaches is not fully known. Impounded sediment volumes and chemical data, together with information regarding the structural integrity of each dam, are necessary to inform decisions regarding potential dam removal projects in the Commonwealth. Accordingly, the U.S. Geological 
Survey (USGS), in cooperation with the MDER, collected baseline information concerning the thickness and volume of impounded bottom sediment and the occurrence of potentially toxic contaminants trapped behind 32 selected dams in Massachusetts. These data may be used to help prioritize dams that pose the greatest risk to the environment in case of either dam failure or purposeful dam breach, as well as identify sediment that may be acting as a present day source of toxic contaminants to the environment.

\section{Purpose and Scope}

This report describes the methods used to measure the thickness, estimate the volume, and collect cores of bottom sediment impounded behind selected dams in Massachusetts. The report also characterizes the chemical quality of the impounded sediment, including sediment-associated inorganic elements and organic compounds. The potential toxicity of the impounded sediment to benthic organisms is assessed by comparing observed concentrations of contaminants to consensus-based sediment quality guidelines. Finally, the report describes and interprets relations among contaminant concentrations in sediment, present day land use, and available indicators of past industrial history in the watersheds of the study impoundments.

\section{Field, Laboratory, and Statistical Methods}

The USGS assessed soft-sediment thicknesses and chemistry in 32 impoundments in Massachusetts by probing with a steel rod and collecting and chemically analyzing sediment cores. Chemical analysis of sediment cores (one homogenized sample per impoundment) included 32 inorganic elements and 108 organic compounds; the organic compounds included polycyclic aromatic hydrocarbons (PAHs), polychlorinated biphenyls (PCBs), and dichlorodiphenyl-trichloroethane (DDT) pesticide compounds. Potential toxicity was estimated using predictive relations between sediment contaminant concentrations and the probable effects on bottom-dwelling (benthic) organisms (Ingersoll and others, 2000; MacDonald and others, 2000). Relations between present day land use and sediment quality were evaluated by means of statistical correlation analysis.

\section{Site Selection and Sampling Techniques}

Dams were selected in consultation with the MDER using several criteria, including the likelihood that the dam might be removed, land use in the upstream drainage basin (ranging from undeveloped to drainage basins with long industrial histories), local interest, and geographical location (fig. 2; table 1).
Soft-sediment thicknesses were measured manually with a steel rod at an average of 20 locations in each of the 32 impoundments; the number of measurements made in the study ranged from 8 to 30 per impoundment. The steel rod was pushed into the soft sediment from a boat or, in cases where impoundments were drained or dams breached, by standing on the sediment surface (fig. 3). Changes in the ease of penetration and the sound emitted from the rod as it was slowly pushed through the soft sediment were interpreted as changes in sediment character. In general, the interface between soft sediment and the original stream channel or flood plain material was felt as an abrupt change in the amount of force necessary to advance the probe. On occasion, this change was accompanied by an audible noise, as the tip of the rod encountered gravel or cobbles that were likely part of the historical flood plain or stream channel. The distance the rod was pushed (minus the measured water depth) was measured and recorded as the soft-sediment thickness. Sediment cores were visually inspected and their length was measured, to verify that soft-sediment thicknesses inferred from probing with the steel rod corresponded to changes in the sediment texture observed in cores from each impoundment in question. The average sediment thickness for an impoundment was calculated by summing the recorded depths and dividing by the number of measurements made in the impoundment.

At least one core was collected from each impoundment. The number and locations of cores collected was determined based on the size of each impoundment and the distribution of the estimated bottom-sediment thicknesses within each impoundment. Each core extended from the sediment water interface to the soft sediment bottom (to a maximum depth of about $8 \mathrm{ft}$ ). Cores were collected from a small boat, a custom-built pontoon boat and platform, or a solid platform placed directly on the sediment surface (fig. 4). Sediment was collected with a coring device comprising a polyethylene piston, a slide hammer, and a disposable polycarbonate core barrel. The core barrel was pushed by hand or hammered into the sediment. Before driving the core barrel into the sediment, the piston was suspended in the core barrel and secured with a steel cable to either the boat gunwale or the platform to keep the piston from moving as the core barrel was pushed into the sediment. Suction produced by the piston minimizes core compaction as the core barrel is pushed forward and helps to retain sediment in the barrel as it is pulled out of the sediment. Sediment cores were retrieved by hand or with a batterypowered winch.

In most cases, the core barrel was pushed past the softsediment bottom into the underlying material; however, in a few cases the soft-sediment thickness was greater than the core barrel length $(8 \mathrm{ft})$. In these cases, the maximum core length was $8 \mathrm{ft}$. After retrieval, the bottom of each core was checked for evidence suggesting that the barrel was pushed deep enough to collect samples representative of the entire softsediment thickness. The end of the core barrel was frequently plugged with either fine gray clay, which was deposited long before the dam was built, or the remains of vegetation that 


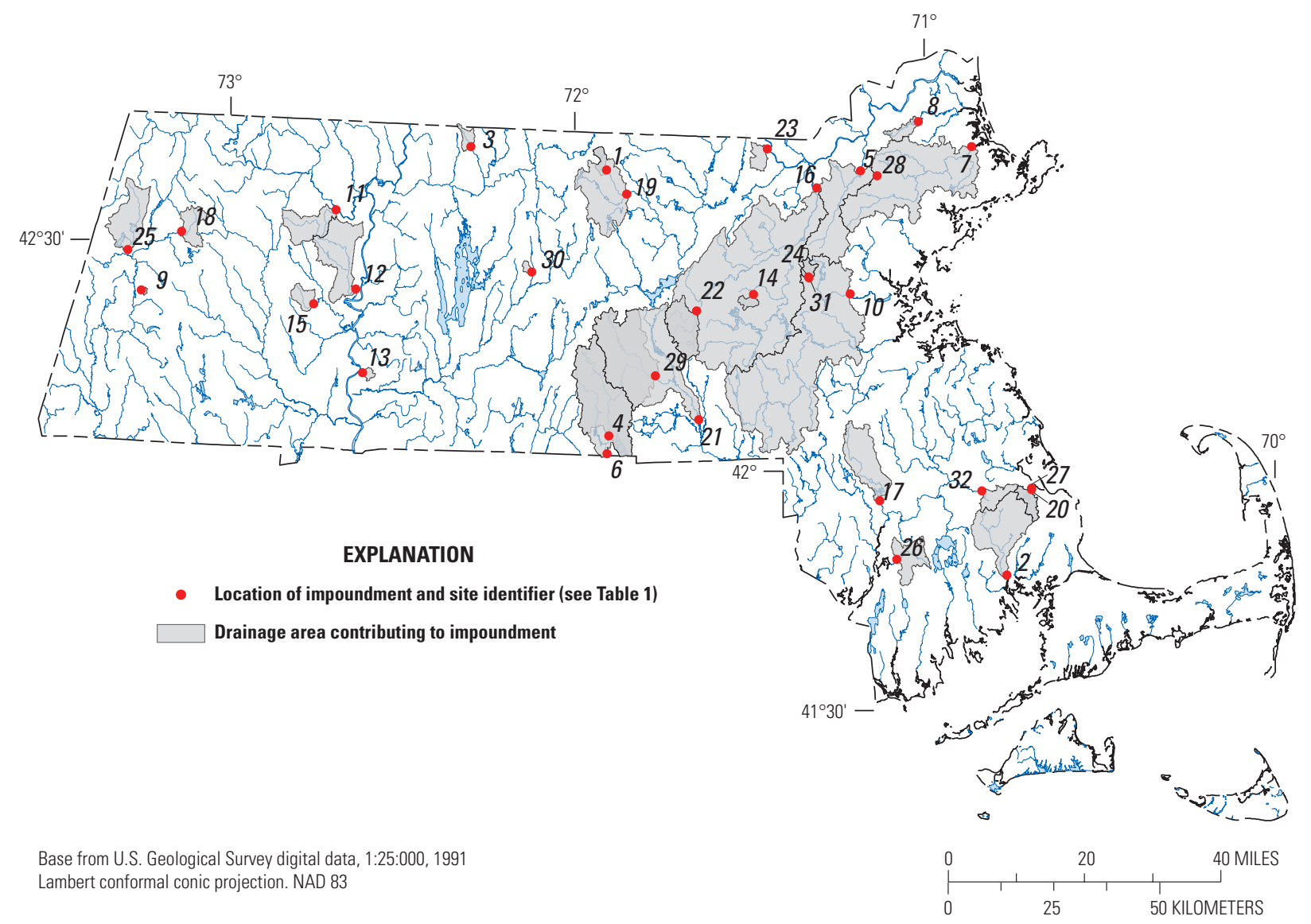

Figure 2. Locations of impoundments in Massachusetts assessed in this study and the drainage areas to the dams that form the impoundments. Sites 24 and 31 are located less than 0.2 mile (mi) apart, and sites 20 and 27 are located less than $0.70 \mathrm{mi}$ apart. Both pairs of sites are shown by a single red symbol. Location data are from the U.S. Army Corps of Engineers (1996).

presumably grew in the flood plain before inundation (fig. 5). If the core barrel appeared not to extend through the entire soft-sediment thickness and the total sediment thickness was less than $8 \mathrm{ft}$, the sample was discarded, the core barrel rinsed with ambient water, and another core was collected. It is important to note that core samples collected from individual impoundments may or may not represent the entire history of sediment deposition, given the limited number of core samples collected and the fact that only one composite sample was submitted for laboratory analyses. As stated above, the dynamic nature of sediment transport in river systems also means that some historically impounded sediment has likely been resuspended and transported downstream by large storms or dam breach or both. In some cases, sediment may have also been previously dredged and disposed of elsewhere during the history of the impoundment.

In the laboratory, cores from each impoundment were homogenized in a precleaned Teflon bag to produce one composite sample for each impoundment. Prior to filling, the Teflon bags were cleaned first with 5-percent hydrochloric acid, then with methanol, and finally with deionized water. Subsamples were collected and placed in precleaned plastic (inorganic elements) or glass (organic compounds) containers for delivery to appropriate analytical laboratories. Samples were shipped on ice in sealed plastic coolers along with accompanying documentation.

\section{Chemical Analysis of Sediment}

Chemical analysis of 32 inorganic elements was done at SGS Laboratory, Lakefield, Ontario, Canada, by means of inductively coupled plasma mass spectrometry (ICP-MS). Chemical analysis of 108 organic compounds was done at the USGS National Water Quality Laboratory (NWQL) in Denver, Colorado, by means of high-resolution gas chromatography/ low-resolution mass spectrometry (HRGC/LRMS). 


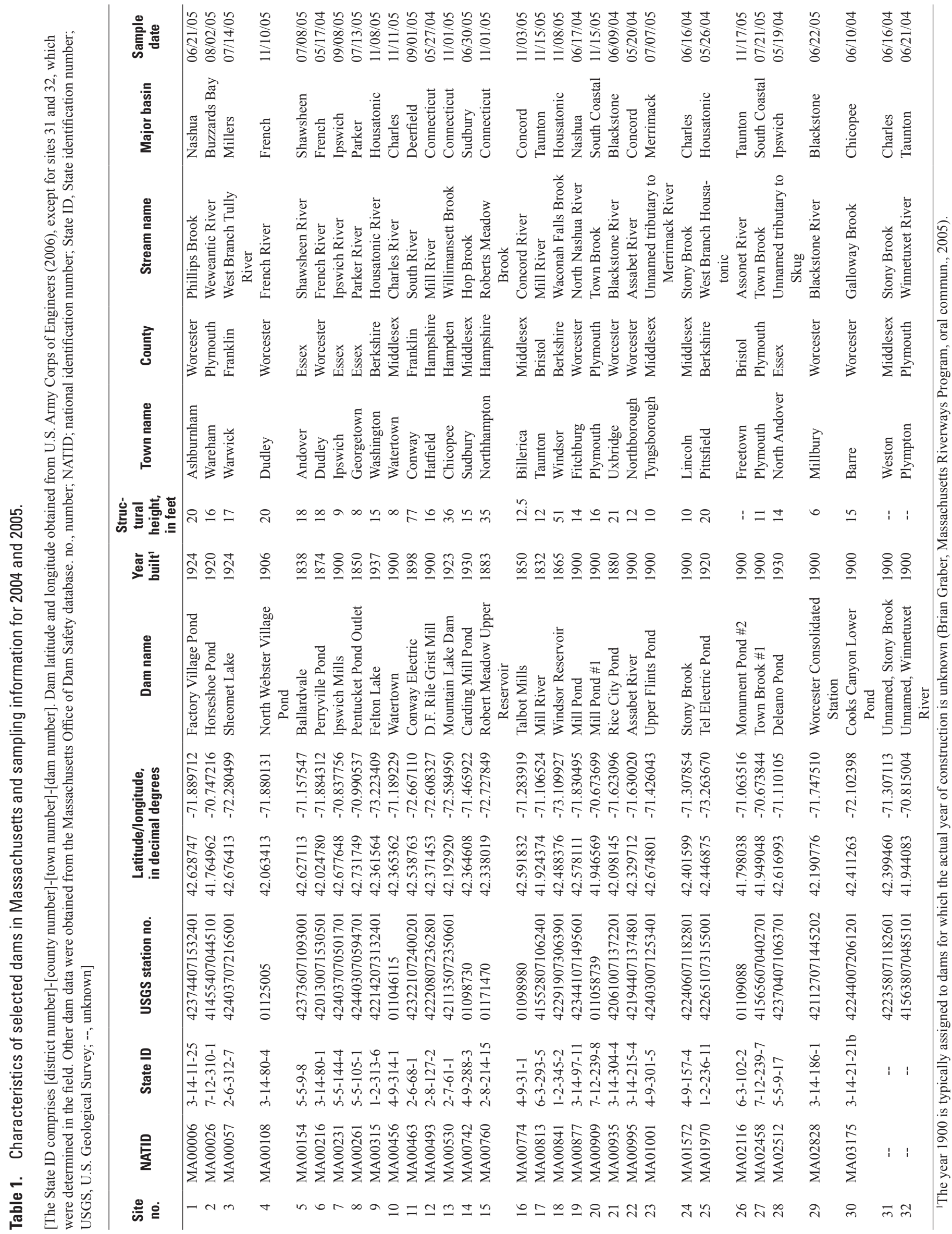


$\boldsymbol{A}$

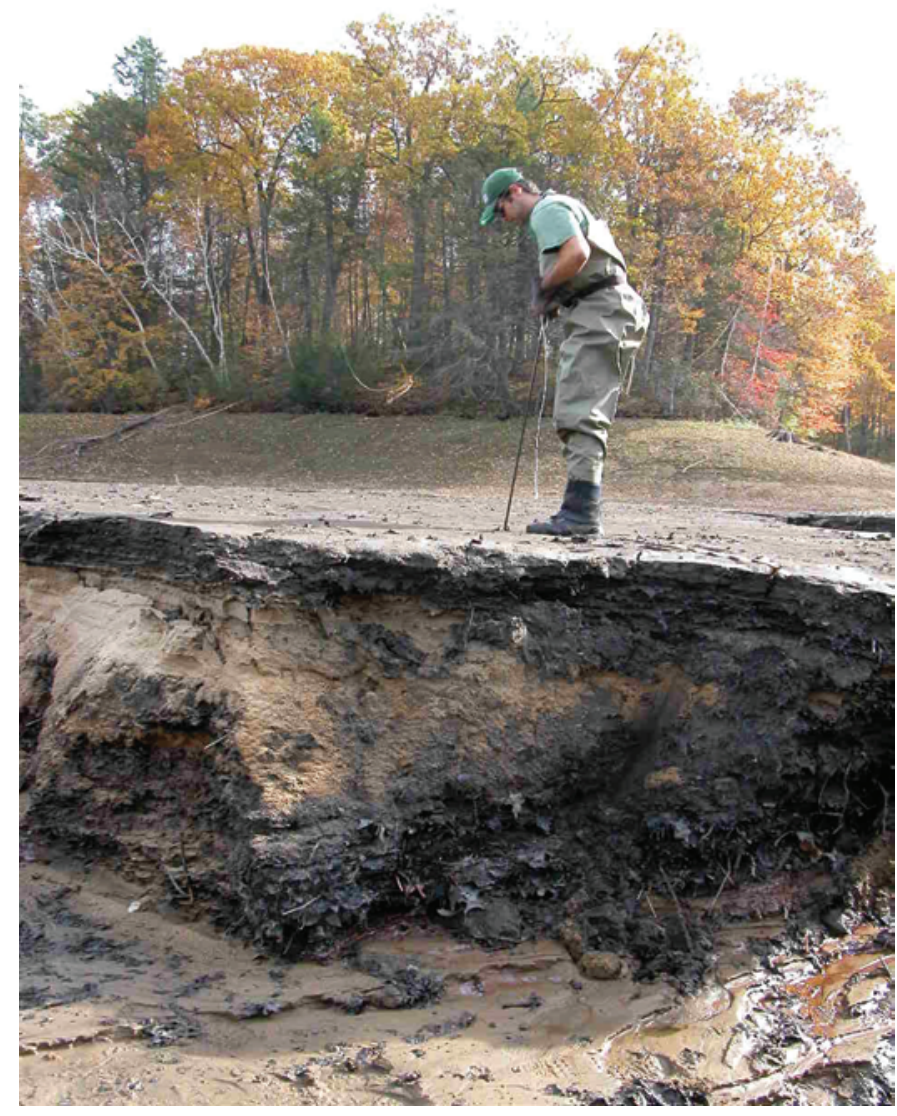

B

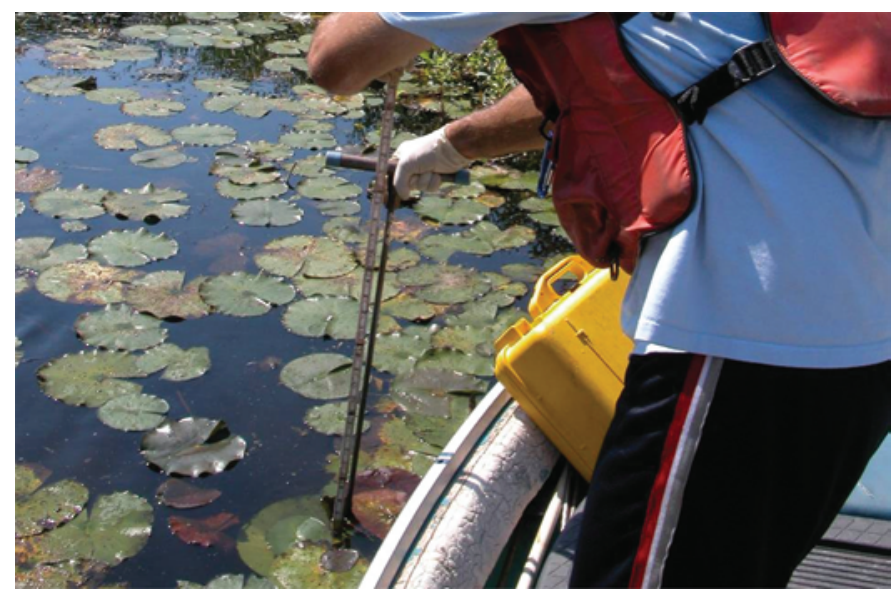

Figure 3. Measurement of soft-sediment thickness where $A$, dam has been breached and the impoundment has been drained and $B$, impoundment is present at the time of sampling.

\section{Analysis of Inorganic Elements}

Before chemical analysis, SGS collected from each sample an unsieved aliquot (about 1 gram). Next, the sample was digested with 2 milliliters $(\mathrm{mL})$ of nitric acid $\left(\mathrm{HNO}_{3}\right)$ and heated at 80 to 90 degrees Celsius for $1 / 2$ hour. After the sample had cooled slightly, the digestates were spiked with $4 \mathrm{~mL}$ of hydrochloric acid $(\mathrm{HCl})$ and heated for 2 hours in a water bath. Next, the digestates were allowed to cool to room temperature and diluted with distilled water to a final volume of $20 \mathrm{~mL}$. About $5 \mathrm{~mL}$ of this solution was poured into a test tube for ICP-MS analysis (U.S. Environmental Protection Agency, 1996).

Environmental samples were analyzed by SGS in batches of up to 40 samples. Each batch was accompanied by quality assurance/quality control (QA/QC) samples - including procedural blanks, laboratory duplicates, matrix-spike samples, and recovery standards - to test laboratory bias and variability. Before analytical results were accepted, QA/QC samples had to meet the following methodology criteria: inorganic element concentrations measured in procedural blanks were required to be less than quantification limits; relative percentage differences (RPDs) between laboratory duplicate and matrix-spike samples were no more than 10 percent; and percent recoveries were within the 50 to 100 percent range. Laboratory instruments were calibrated in accordance with the standard operating procedures of SGS and were required to meet method specifications (SGS Laboratory, written commun., 2006).

\section{Organic Analysis}

The day before the chemical analysis, the USGS laboratory extracted unsieved sediment overnight with dichloromethane in a Soxhlet apparatus and split into two aliquots (Foreman and others, 1995; Furlong and others, 1996). The first aliquot was analyzed for PAHs and alkyl-PAHs by capillary column gas chromatography with detection by mass spectrometry (Furlong and others, 1996). The second aliquot was analyzed for chlorinated hydrocarbons by dual capillary column gas chromatography with electron capture detection (Noriega and others, 2004).

Environmental samples were analyzed at the USGS National Water Quality Laboratory (NWQL) in batches of up to 12 samples. Each batch was accompanied by QA/QC samples - including procedural blanks, laboratory duplicates, matrix-spike samples, and recovery standards - to test laboratory bias and variability (Noriega and others, 2004). Before analytical results were accepted, QA/QC samples had to meet the following methodology criteria: chemical concentrations measured in procedural blanks were less than quantification limits; RPDs between laboratory duplicate and matrix-spike samples were no more than 10 percent; and percent recovery ranges were within 50 to 120 percent. Laboratory instruments were calibrated in accordance with the standard operating procedures of the USGS and were required to meet method specifications. 


\section{$\boldsymbol{A}$}

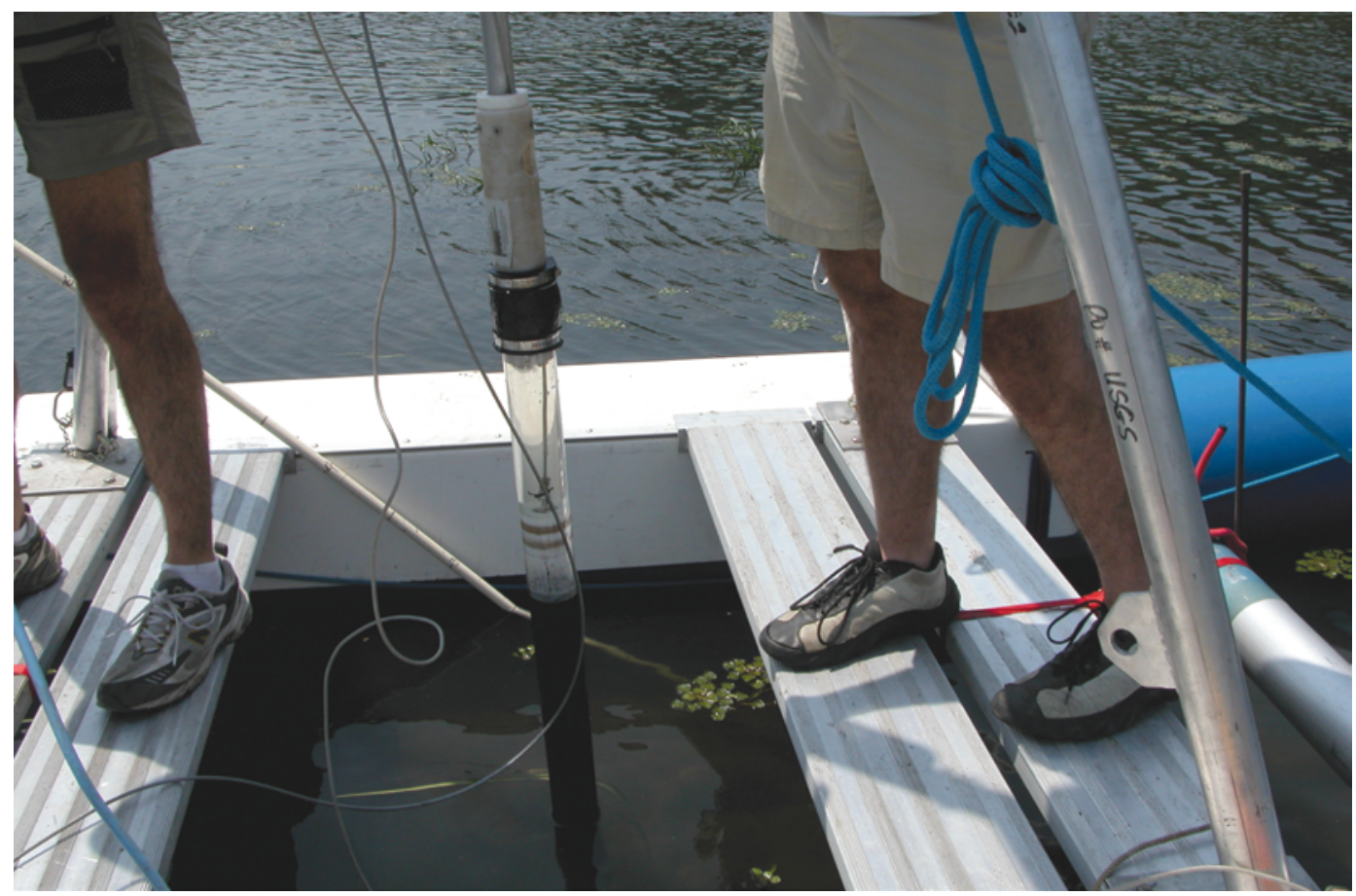

\section{B}

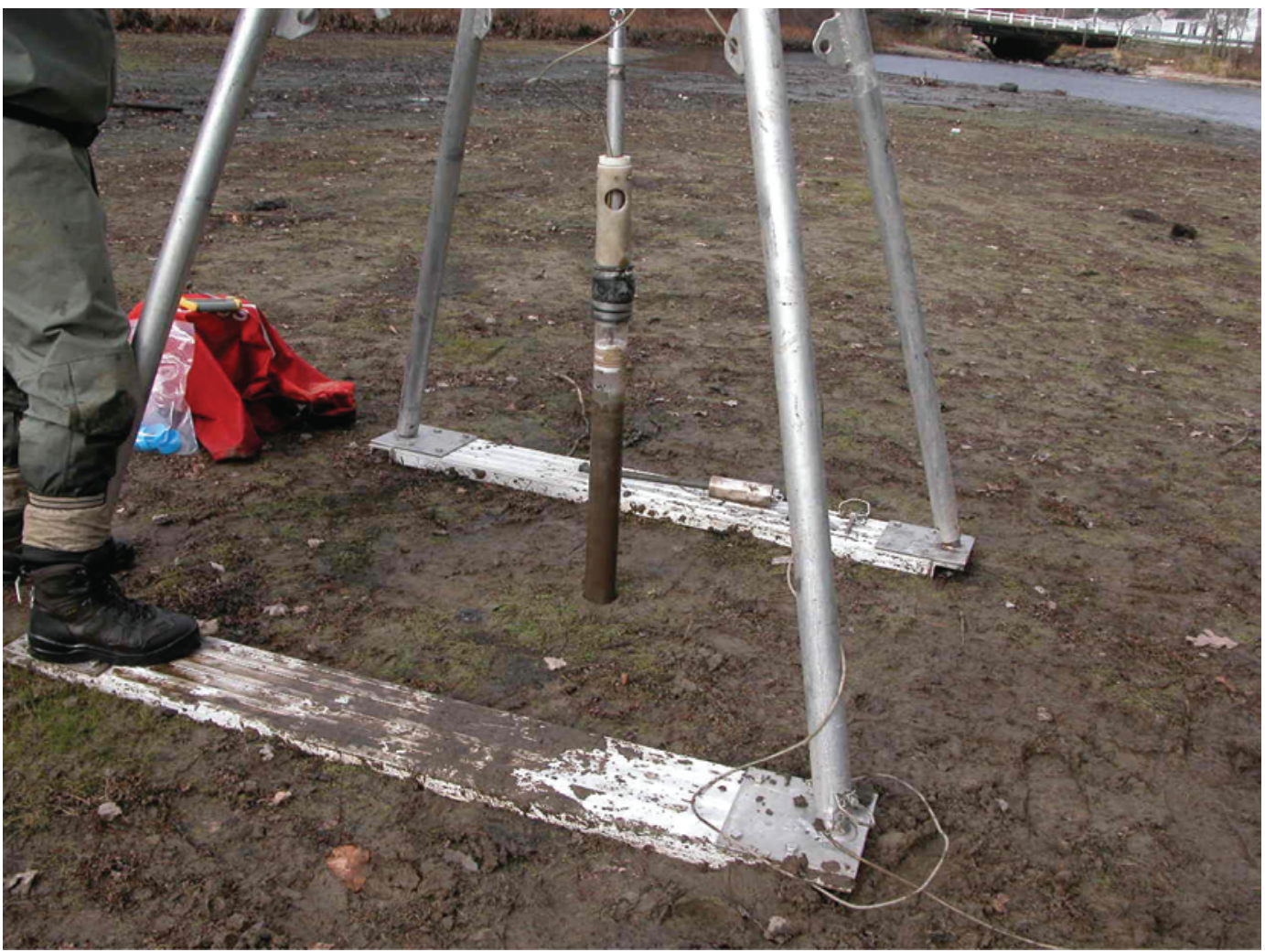

Figure 4. Methods used to obtain cores from impoundments. Cores were collected $A$, from floating pontoon or $B$, at the sediment surface where the impoundment has been drained. 


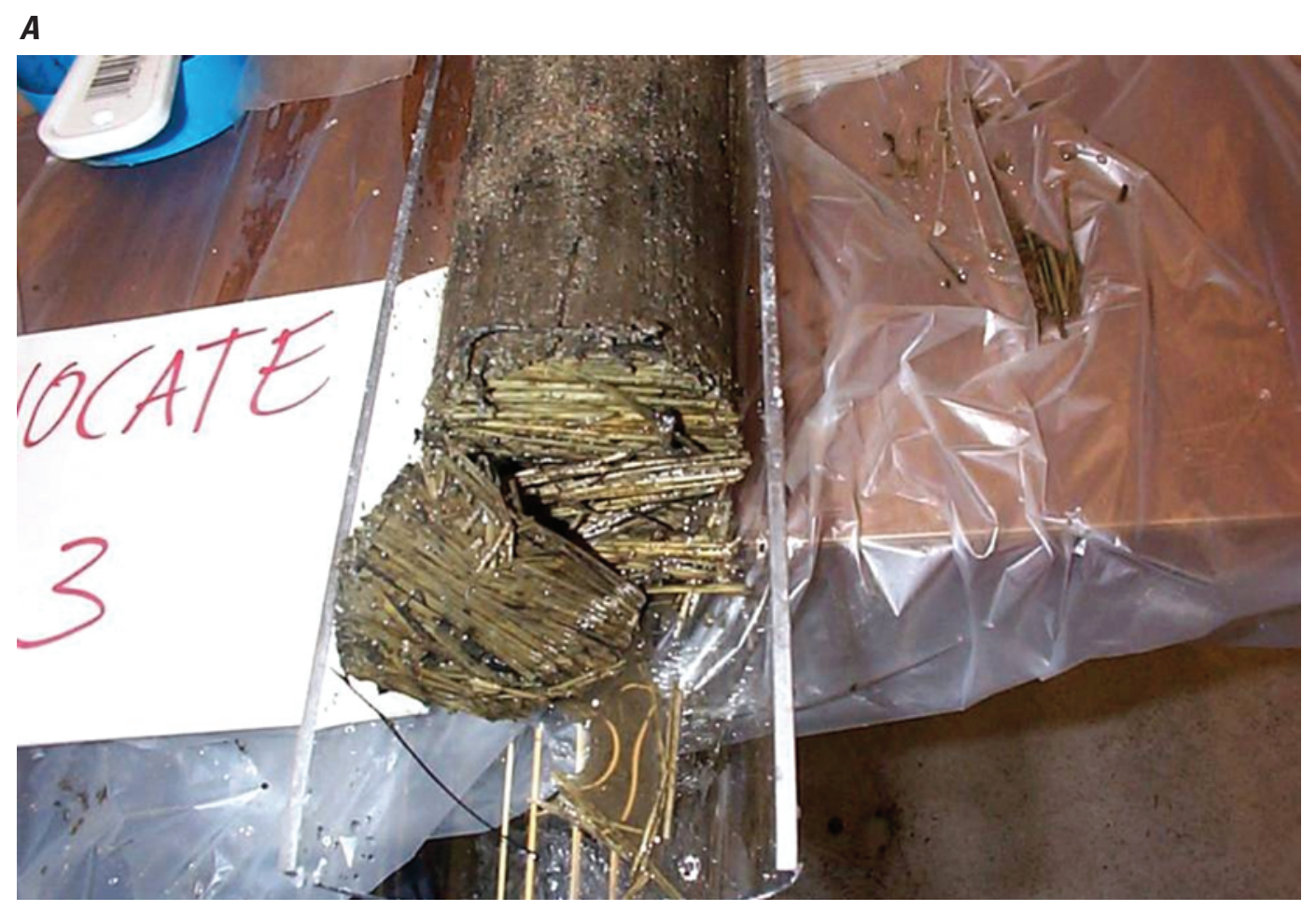

B

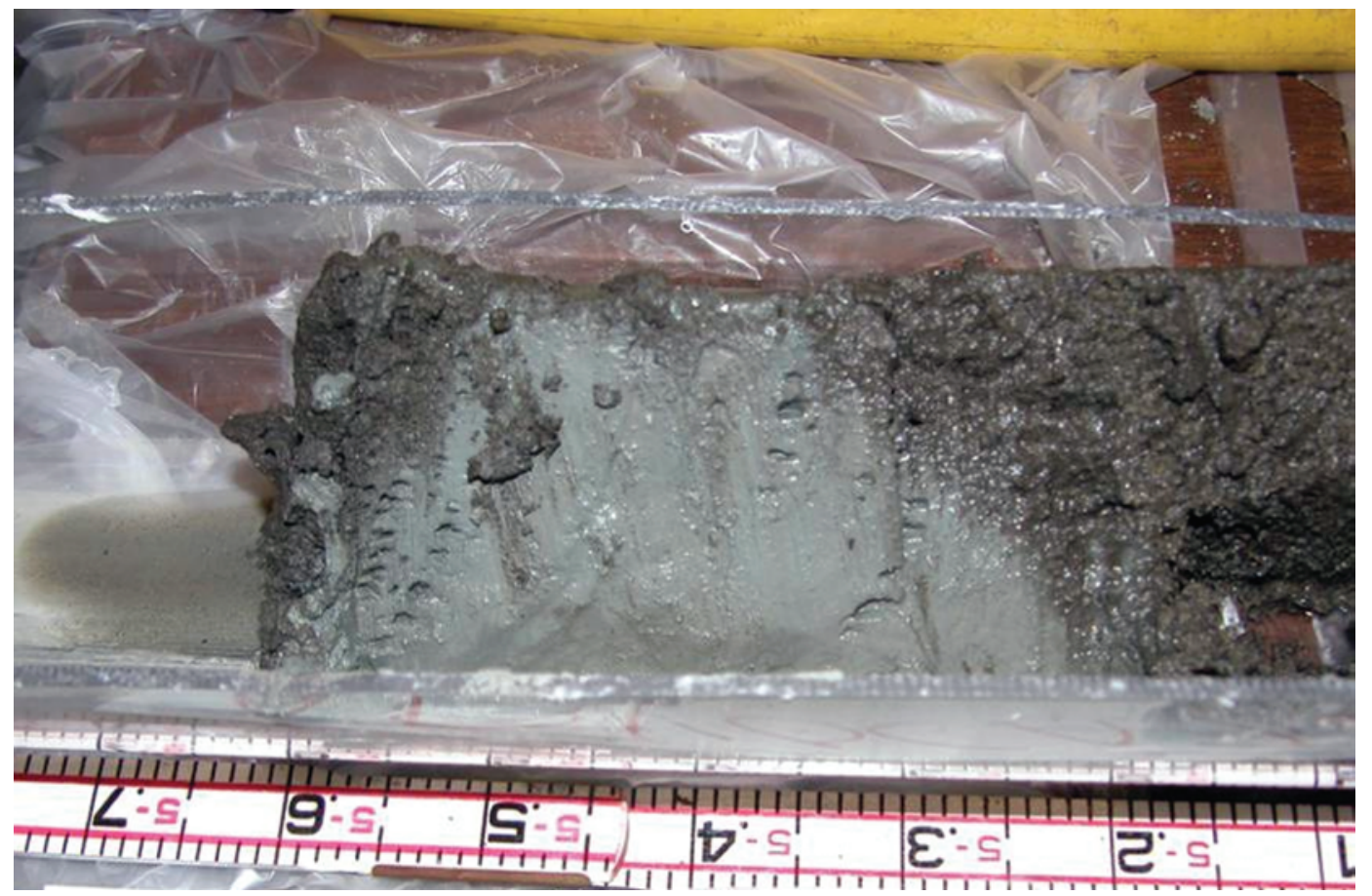

Figure 5. Examples of core penetration through the full thickness of impounded sediment into preimpoundment material. Core samples contain $A$, floodplain vegetation, and $B$, inorganic clay. 


\section{Bias and Variability in Field and Laboratory Analyses}

Environmental samples were collected and analyzed along with field duplicates (or split samples) and blind reference samples. These QA/QC samples were collected, processed, and analyzed in exactly the same way as the environmental samples. Therefore, the field QA/QC samples can be used to assess bias and variability associated with environmental conditions, sample collection, and sample processing as well as with laboratory processing. Field duplicates were collected at 3 of 32 locations and consisted of two representative aliquots of sediment that were taken from the homogenized sample and were analyzed separately. RPDs for detectable inorganic element concentrations between field duplicate samples averaged 2.9 percent, with one exception. The RPD for detectable molybdenum concentration measured in the Mountain Lake impoundment field duplicate sample (site 13) was 66 percent. Blind reference samples for the inorganic elements, consisting of National Institute of Standards and Technology (NIST) standard reference material (SRM) 2711 Montana Soil, were submitted to SGS for analysis. RPDs between the SGS-reported inorganic element concentrations and the NIST-certified values for the blind samples were all less than 15 percent, with the exception of that for titanium, which had an RPD of about 28 percent. Field duplicate samples were not analyzed for organic compounds.

Quality assurance for organic constituents was conducted at the NWQL. No blind reference samples were submitted to NWQL. However, percent recovery of laboratory surrogate organic constituents ranged between 30 and 95 percent, and RPDs between sample and replicate results were less than 25 percent for 103 of the 115 constituents investigated for two of the replicate sample pairs and less than 25 percent for 88 of the constituents for the third replicate sample pair. Average and median RPDs between all replicate sample pairs were 18 and 6 percent, respectively.

Concentrations of inorganic elements and organic compounds greater than the detection limit indicate that the compound concentration is greater than the laboratory reporting level (LRL) for a given analytical technique. Nondetection may indicate either that the compound is not present in the sample or that the concentration of the compound in the sample is less than the LRL for the analytical technique used. The LRL is generally equal to twice the long-term method detection limit (LT-MDL) for a given analyte and laboratory method (Childress and others, 1999).

\section{Estimated Toxicity of Sediment}

The consensus-based sediment quality guidelines (Ingersoll and others, 2000; MacDonald and others, 2000) were used in this study to compare impounded-sediment chemistry results to predicted impacts on benthic dwelling organisms. It is important to note that these guidelines are empirical, effects-based thresholds derived from laboratory toxicology tests on a limited range of organisms. As such, the thresholds do not account for chronic toxicity that results from prolonged exposure, toxicity caused by mixtures of chemicals, nor to biological availability of contaminants or other mortality drivers that may be governed by environmental conditions. For example, high sediment-oxygen demand (SOD) may result in low dissolved oxygen (DO) concentrations that can be lethal to some aquatic organisms; by contrast, acid-volatile sulfides (AVS) may chemically bind some toxic chemicals making them biologically immobile.

Nevertheless, estimation of sediment toxicity from concentrations of common contaminants and known threshold effect concentrations (TECs) and probable effect concentrations (PECs) has been shown to be a reasonable predictor of toxicity in a laboratory setting for a limited range of organisms (Ingersoll and others, 2000; MacDonald and others, 2000). The TEC for a given contaminant is defined as the concentration below which harmful effects are unlikely to be observed, and the PEC is defined as the concentration above which effects are likely to be observed (MacDonald and others, 2000).

Understanding of potential sediment toxicity is facilitated by determination of PEC quotients (PECQs) for individual contaminants within a sample (MacDonald and others, 2000). The PECQ is defined as the ratio of the concentration of a contaminant in a sample to the contaminant PEC. To obtain an estimate of the overall toxicity of a sediment sample $x$, the PECQs for the individual contaminants (and contaminant groups) in a sample are averaged to obtain the overall sample PECQ, also known as the $P E C Q_{x}$, as follows:

$$
P E C Q_{x}=\frac{\sum \frac{C_{x, y}}{P E C_{y}}}{n_{x}},
$$

where

$$
\begin{aligned}
P E C Q_{x} & \text { is the average PECQ for sediment sample } x, \\
C_{x, y} & \text { is the concentration of contaminant } y \text { or } \\
& \text { contaminant group } y \text { in sample } x,
\end{aligned}
$$

Before calculating the $P E C Q_{x}$, the contaminant concentrations are first adjusted for censored data (data below the laboratory reporting level). In accordance with the practice of Breault and others $(2005$, p. 10), censored data were set equal to zero in the calculation of the PECQ and $P E C Q_{x}$ values. Consequently, our approach to the calculation of $P E C Q_{x}$ for a sample does not include any toxicity associated with undetected constituents. 
In the current study, 10 PECQs (for arsenic, cadmium, chromium, copper, lead, nickel, and zinc, total PAHs, total PCBs, and total DDTs) were averaged to determine a $P E C Q_{x}$ for each sample. For the purposes of this report, total PAHs equal the sum of anthracene, benzo(a)anthracene, benzo(a) pyrene, chrysene, 9H-fluorene, fluoranthene, naphthalene, phenanthrene, and pyrene; total PCBs equal the sum of all polychlorinated biphenyl congeners; and total DDTs equal the sum of ortho,para'-DDE, para,para'-DDE, ortho,para'-DDD, para,para'-DDD, ortho,para'-DDT, and para,para'-DDT.

The probability of observing sediment toxicity in a sample may be estimated from the $P E C Q_{x}$ using the following equation (MacDonald and others, 2000):

$$
Y=101.48 \times\left(1-0.36^{x}\right)
$$

where

$Y \quad$ is the estimated probability of toxicity, in percent; and

$x \quad$ is the average probable effects quotient for a sample $\left(P E C Q_{x}\right)$; as calculated in equation 1 .

\section{Sediment Thickness, Chemical Quality, and Estimated Toxicity}

The thickness, chemical quality, and estimated toxicity of bottom sediment were assessed at each of the 32 impoundments selected for this study. Major results are presented in the following sections.

\section{Measured Sediment Thicknesses and Estimated Volumes}

Average sediment thicknesses ranged from 0.5 to $6.7 \mathrm{ft}$ among the impoundments, with an overall average of $3.7 \mathrm{ft}$ (table 2). Minimum sediment thicknesses ranged from 0 to $2.6 \mathrm{ft}$. The maximum measured sediment thickness was about $15 \mathrm{ft}$ (D.F. Rile Grist Mill Dam, site 12). At the Conway Electric Dam on the South River in Conway (site 11), sediment thicknesses were found to be greater than what could be feasibly measured with a steel rod (greater than $20 \mathrm{ft}$ ). At the Pentucket Pond Outlet and Carding Mill Dams (sites 8 and 14), local field conditions precluded collection of thickness data. For these reasons, estimates of sediment volume could not be calculated for these three sites. At all other sites, surface areas reported in the NID for each impoundment (U.S. Army Corps of Engineers, 1996) were multiplied by average thicknesses to give planning-level estimates of sediment volumes (table 2). Sediment volumes estimated in this manner ranged from 110,000 $\mathrm{ft}^{3}$ (Deleano Pond Dam on an unnamed tributary of the Skug River in North Andover, site 28) to 81 million cubic feet $\left(\mathrm{Mft}^{3}\right.$; Talbot Mills Dam on the Concord River in Billerica, site 16). It is important to note that sediment may not accumulate in a uniform manner behind a dam; commonly it forms a wedge shape based upon the gradual settling of different grain sizes in response to reduced water velocities within an impoundment. Therefore, actual volumes of impoundment sediment may be greater or less than the estimated volumes presented here.

\section{Concentrations of Inorganic Elements}

Contaminant concentrations in the sediment cores (inorganic elements and organic compounds) varied substantially among impoundments. Many of these contaminants are on the U.S. Environmental Protection Agency list of 126 priority pollutants (U.S. Environmental Protection Agency, undated). The priority pollutant elements arsenic, chromium, copper, lead, nickel, and zinc were detected at all 32 impoundment sites.

The priority pollutant element cadmium was detected at 14 of the 32 sites.

The highest concentrations of the inorganic elements copper, nickel, and zinc were measured at the Worcester Consolidated Station Dam (site 29) on the Blackstone River in Millbury (fig. 6; table 3). This finding is consistent with the long industrial history of the Blackstone River and its watershed, which, together with the Charles River, is considered the birthplace of the industrial revolution in Massachusetts (Brown and Tager, 2000, p. 121). Among the 32 impoundment sites, the highest concentrations of the inorganic elements arsenic, cadmium, chromium, and lead were measured at the Mill Pond Dam \#1 on the Town Brook in Plymouth (site 20), the Mill Pond Dam on the North Nashua River in Fitchburg (site 19), the Perryville Pond Dam on the French River in Dudley (site 6), and the Tel Electric Pond Dam on the West Branch Housatonic in Pittsfield (site 25), respectively. The Rice City Pond Dam on the Blackstone River in Uxbridge (site 21) also had relatively higher concentrations of the priority pollutant elements than most other sites, with the second highest concentrations of cadmium, chromium, copper, and nickel and the third highest concentrations of lead and zinc among the 32 sites (fig. 6). 
Table 2. Bottom-sediment thicknesses and estimated volumes of sampled impoundments in Massachusetts in 2004 and 2005.

[Estimated sediment volumes are rounded values. no., number; $\mathrm{ft}$, feet; $\mathrm{ft}^{2}$, square feet; $\mathrm{ft}^{3}$, cubic feet; --, not sampled]

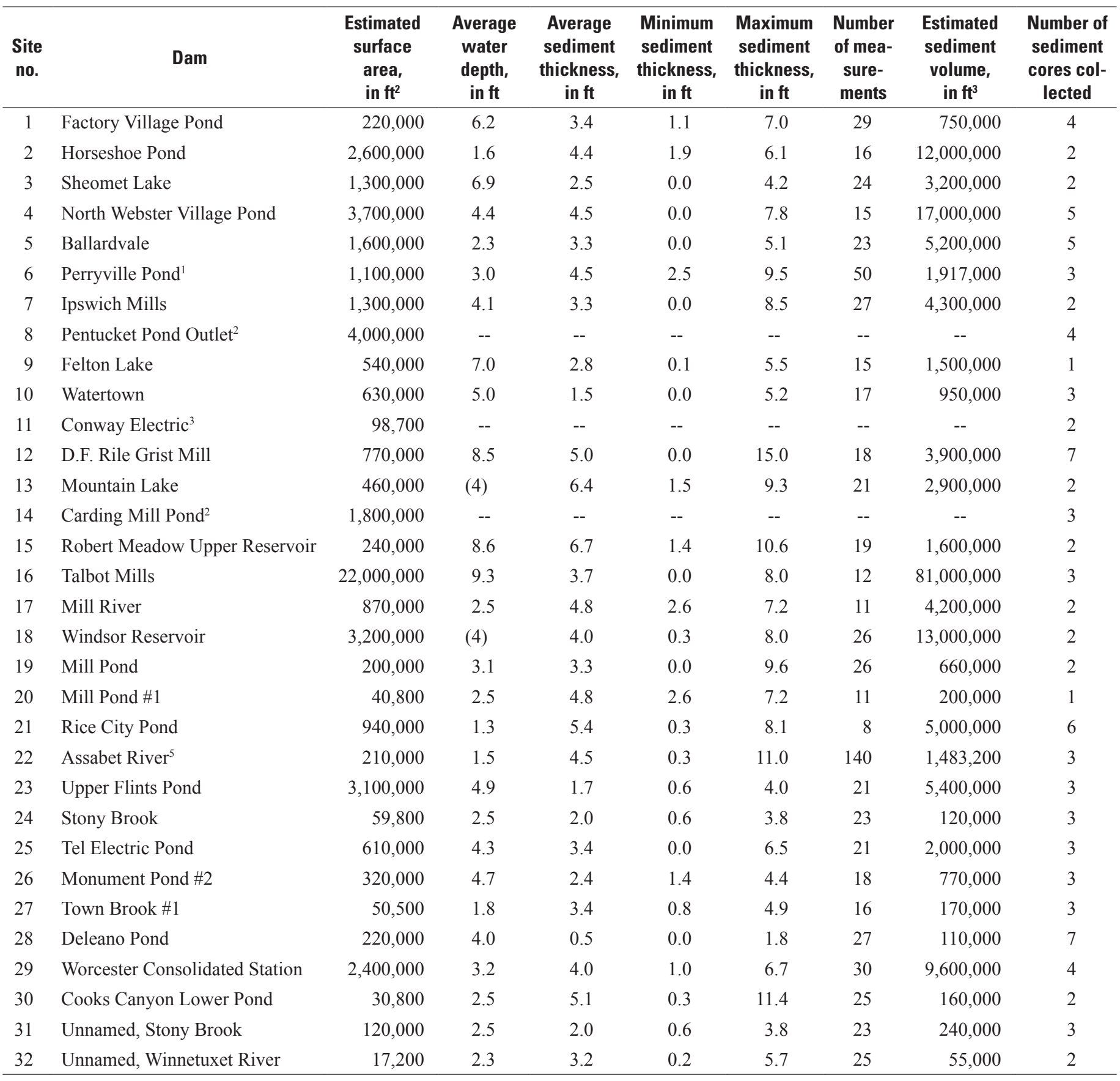

${ }^{1}$ Data from Zimmerman and Breault (2003).

${ }^{2}$ Field conditions precluded measurement.

${ }^{3}$ Thickness greater than $20 \mathrm{ft}$ probe length.

${ }^{4}$ Impoundment was dry at time of measurement.

${ }^{5}$ Data from Zimmerman and Sorenson (2005). 


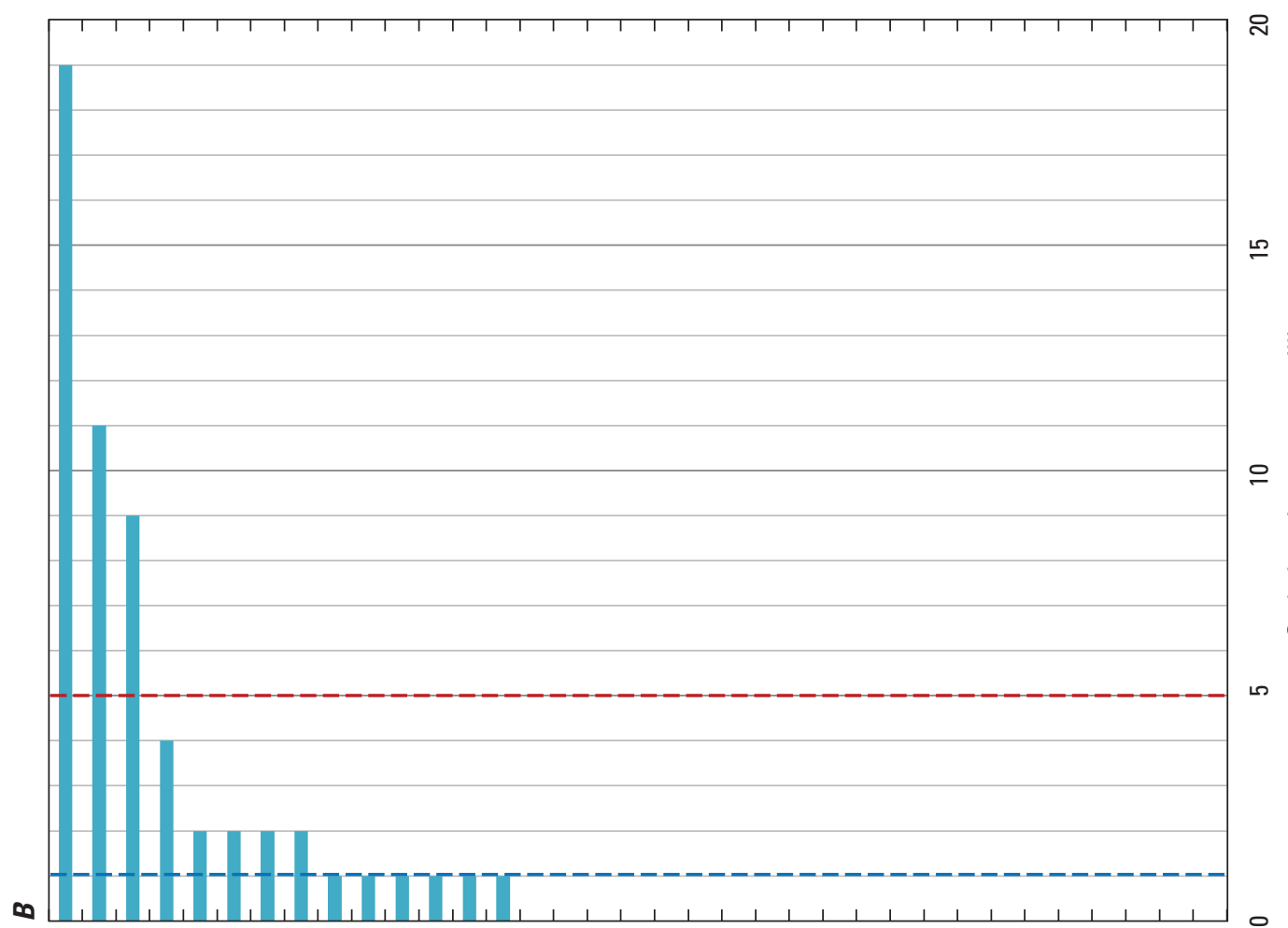

믐ํㅇำの ıәqunu әџ!

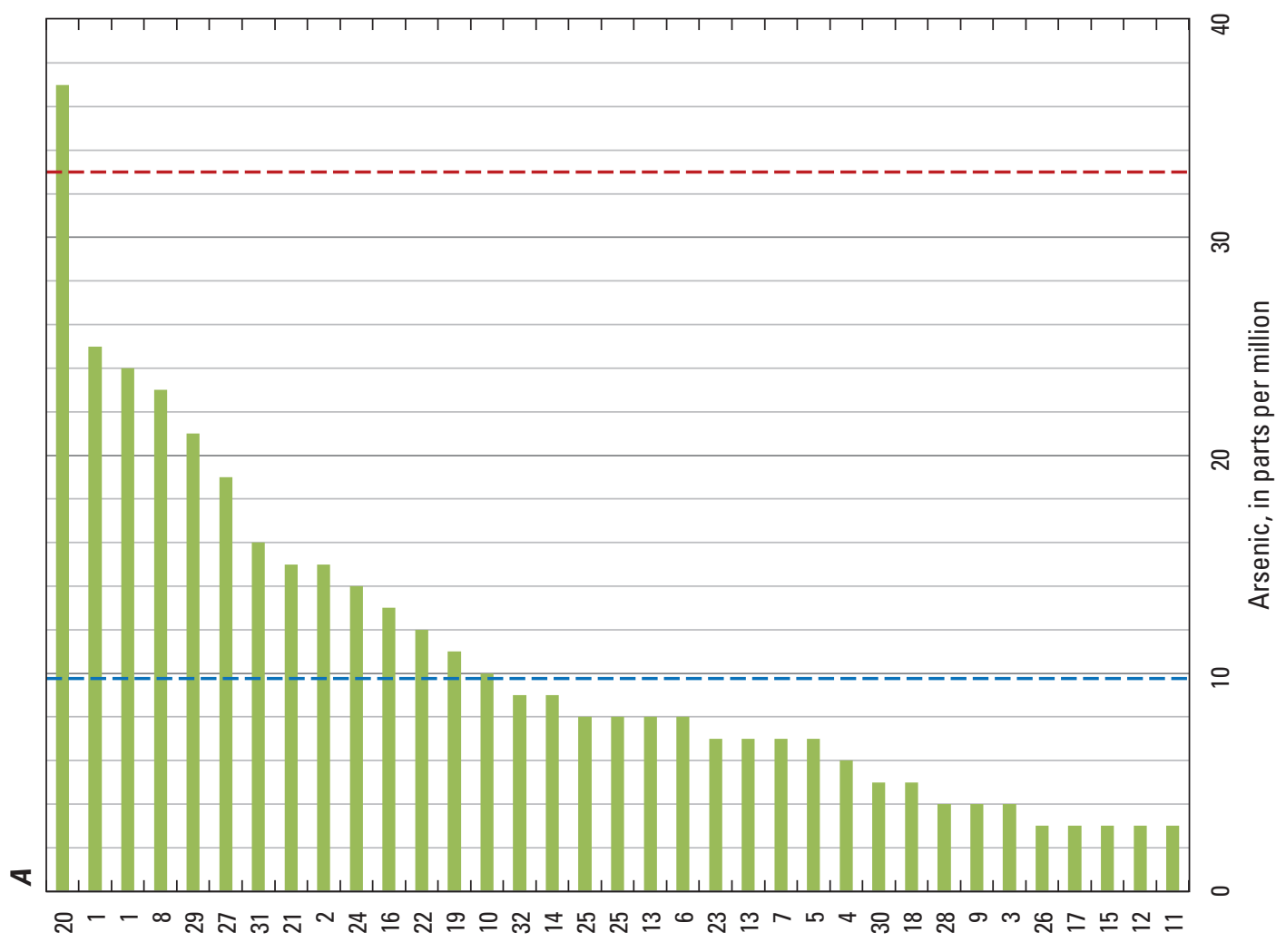
ıәqunu әџ!

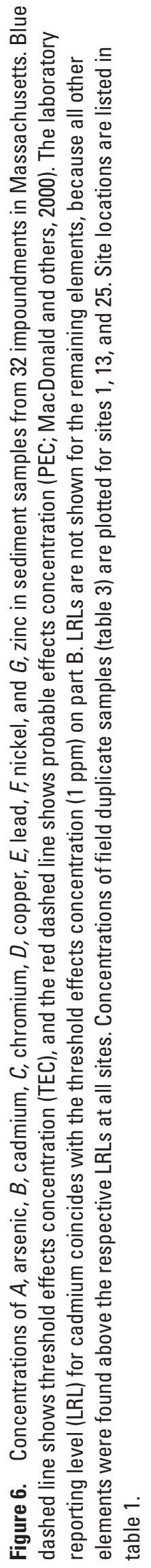



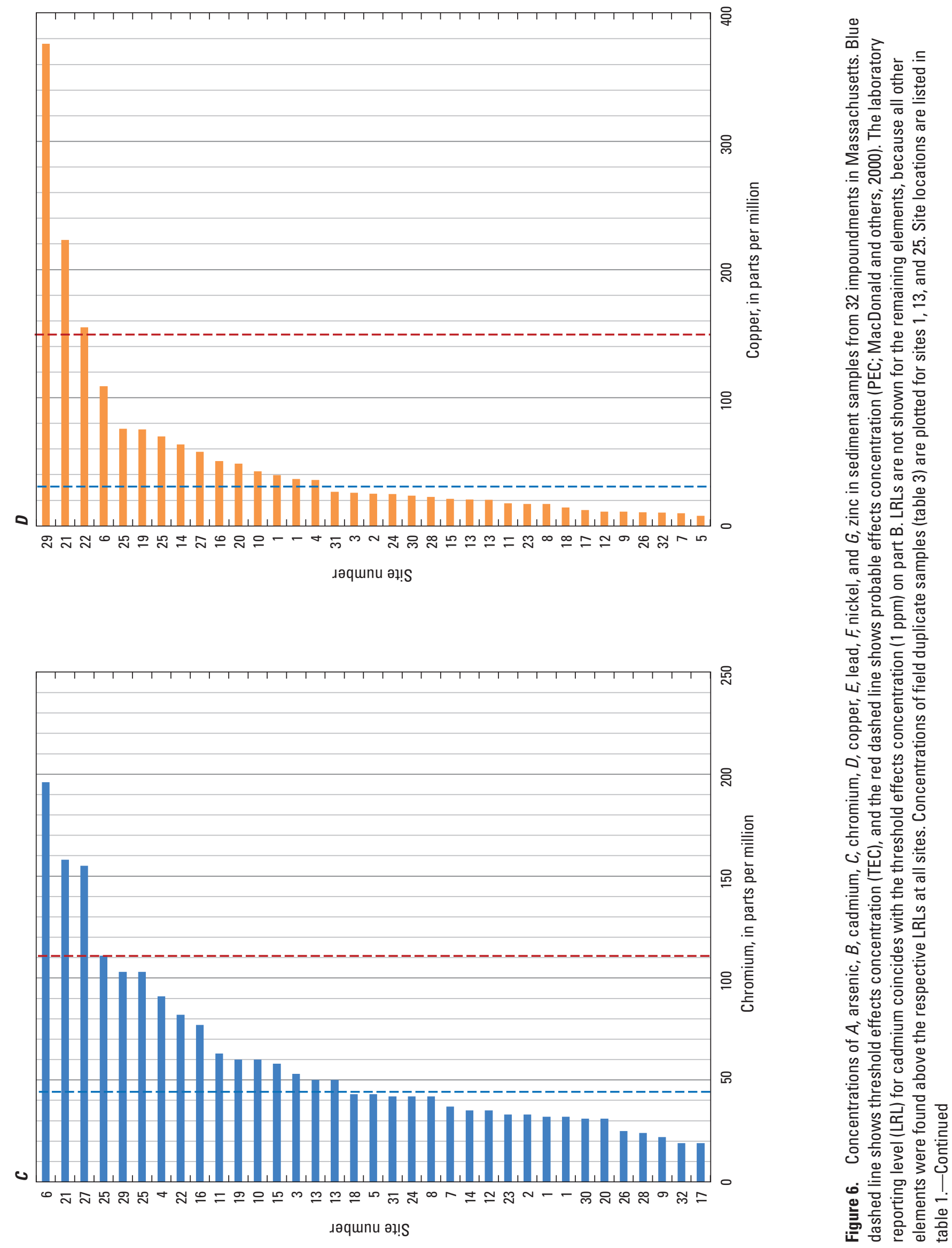

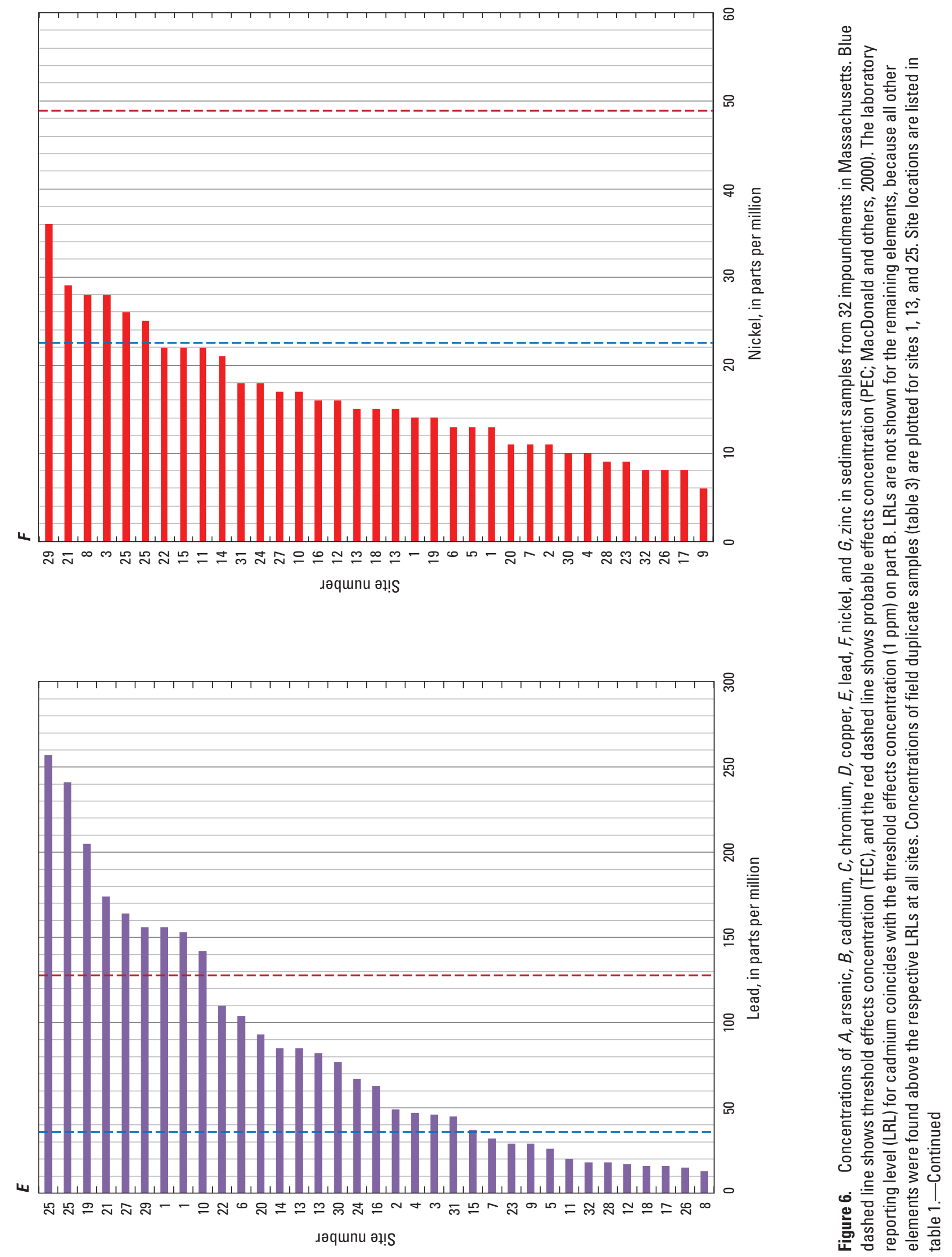

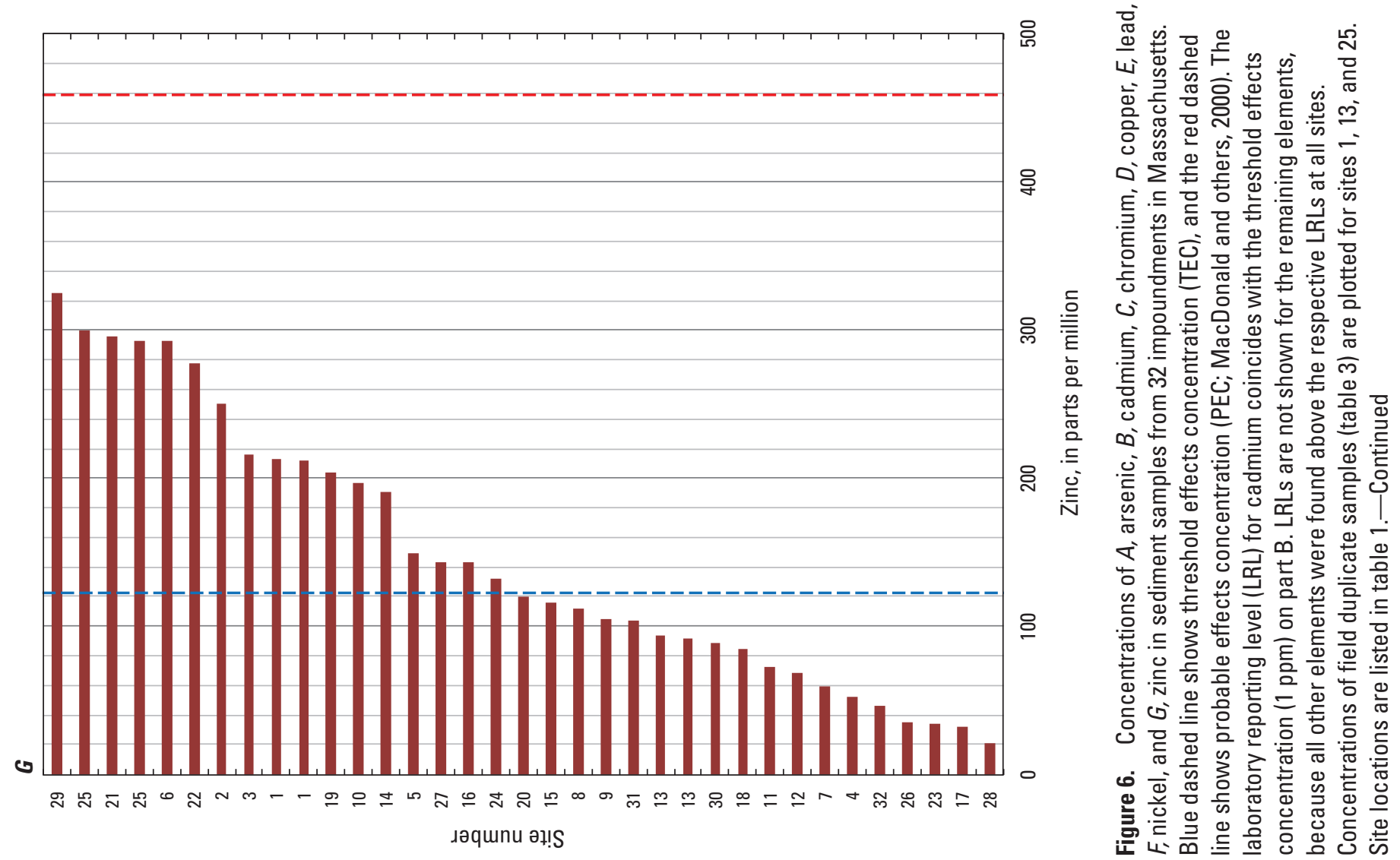
Table 3. Concentrations of inorganic elements measured in bottom-sediment cores collected from selected impoundments in Massachusetts in 2004 and 2005.

[Concentrations were determined on unmilled samples using method 3050b digestion from U.S. Environmental Protection Agency (1996). DUP, field duplicate sample; no., number; ppm, parts per million; \%, percent; <, less than value shown]

\begin{tabular}{|c|c|c|c|c|c|c|c|c|c|c|c|}
\hline $\begin{array}{l}\text { Site } \\
\text { no. }\end{array}$ & Dam name & $\begin{array}{l}\text { Beryll- } \\
\text { lium, } \\
\text { in ppm }\end{array}$ & $\begin{array}{c}\text { So- } \\
\text { dium, } \\
\text { in \% }\end{array}$ & $\begin{array}{l}\text { Magne- } \\
\text { sium, } \\
\text { in \% }\end{array}$ & $\begin{array}{c}\text { Alumi- } \\
\text { num, } \\
\text { in \% }\end{array}$ & $\begin{array}{c}\text { Phos- } \\
\text { phorus, } \\
\text { in } \%\end{array}$ & $\begin{array}{l}\text { Potas- } \\
\text { sium, } \\
\text { in \% }\end{array}$ & $\begin{array}{l}\text { Cal- } \\
\text { cium, } \\
\text { in \% }\end{array}$ & $\begin{array}{l}\text { Scan- } \\
\text { dium, } \\
\text { in ppm }\end{array}$ & $\begin{array}{l}\text { Tita- } \\
\text { nium, } \\
\text { in \% }\end{array}$ & $\begin{array}{l}\text { Vana- } \\
\text { dium, } \\
\text { in ppm }\end{array}$ \\
\hline 1 & Factory Village Pond & 4.2 & 1.08 & 0.28 & 5.91 & 0.15 & 2.19 & 0.6 & 5.3 & 0.2 & 46 \\
\hline 2 & Horseshoe Pond & 1.5 & 0.89 & 0.2 & 3.73 & 0.1 & 1.06 & 0.56 & 4.3 & 0.19 & 54 \\
\hline 3 & Sheomet Lake & 1.9 & 0.8 & 0.58 & 5.46 & 0.12 & 0.85 & 0.87 & 10 & 0.29 & 94 \\
\hline 4 & North Webster Village Pond & 2.1 & 1.12 & 0.3 & 4.75 & 0.04 & 1.48 & 0.99 & 3.9 & 0.16 & 27 \\
\hline 5 & Ballardvale & 2.4 & 1.11 & 0.36 & 4.73 & 0.05 & 1.51 & 1.01 & 4.6 & 0.18 & 36 \\
\hline 6 & Perryville Pond & 2.2 & 1.1 & 0.31 & 4.57 & 0.07 & 1.5 & 0.93 & 4.2 & 0.16 & 33 \\
\hline 7 & Ipswich Mills & 1.7 & 1.36 & 0.39 & 4.82 & 0.03 & 1.73 & 0.76 & 4 & 0.12 & 36 \\
\hline 8 & Pentucket Pond Outlet & 1.2 & 0.44 & 0.33 & 2.4 & 0.05 & 0.52 & 1.18 & 3.3 & 0.08 & 31 \\
\hline 9 & Felton Lake & 1.7 & 0.99 & 0.28 & 4.54 & 0.23 & 0.86 & 1.22 & 9.2 & 0.51 & 37 \\
\hline 10 & Watertown & 1.8 & 1.36 & 0.68 & 5.47 & 0.09 & 1.66 & 1.26 & 7.8 & 0.33 & 78 \\
\hline 11 & Conway Electric & 1.9 & 1 & 1 & 6.15 & 0.06 & 1.22 & 1.42 & 15.3 & 0.3 & 93 \\
\hline 12 & D.F. Rile Grist Mill & 1.6 & 1.43 & 0.67 & 5.62 & 0.05 & 1.22 & 1.27 & 9.8 & 0.28 & 70 \\
\hline 13 & Mountain Lake & 2.1 & 1.53 & 0.55 & 6.39 & 0.1 & 1.66 & 1.32 & 8 & 0.3 & 68 \\
\hline 14 & Carding Mill Pond & 2.4 & 0.78 & 0.26 & 3.73 & 0.25 & 0.88 & 1.32 & 4.7 & 0.16 & 36 \\
\hline 15 & Robert Meadow Upper Reservoir & 2.9 & 1.12 & 0.56 & 6.45 & 0.09 & 1.52 & 1.12 & 9.8 & 0.31 & 83 \\
\hline 16 & Talbot Mills & 1.9 & 0.97 & 0.25 & 4.02 & 0.1 & 1.3 & 0.98 & 3.6 & 0.1 & 30 \\
\hline 17 & Mill River & 1.5 & 1.45 & 0.25 & 4.57 & 0.03 & 1.6 & 0.83 & 4.3 & 0.21 & 36 \\
\hline 18 & Windsor Reservoir & 1.5 & 0.87 & 0.64 & 5.48 & 0.07 & 2.17 & 0.84 & 7.3 & 0.28 & 61 \\
\hline 19 & Mill Pond & 2.7 & 1.05 & 0.24 & 7.07 & 0.07 & 1.58 & 0.67 & 5.4 & 0.45 & 50 \\
\hline 20 & Mill Pond \#1 & 1.5 & 0.6 & 0.22 & 2.84 & 0.07 & 0.88 & 0.41 & 3.3 & 0.14 & 42 \\
\hline 21 & Rice City Pond & 1.9 & 1.08 & 0.36 & 4.71 & 0.18 & 1.54 & 0.8 & 4.9 & 0.21 & 43 \\
\hline 22 & Assabet River & 2.1 & 1.19 & 0.62 & 5.53 & 0.14 & 1.27 & 1.22 & 8 & 0.25 & 63 \\
\hline 23 & Upper Flints Pond & 2.2 & 1.14 & 0.21 & 4.18 & 0.06 & 1.47 & 0.87 & 3.3 & 0.14 & 21 \\
\hline 24 & Stony Brook & 1.6 & 0.81 & 0.48 & 4.05 & 0.11 & 0.89 & 1.31 & 5.7 & 0.2 & 61 \\
\hline 25 & Tel Electric Pond & 1.5 & 0.56 & 1.66 & 5.18 & 0.08 & 1.71 & 2.52 & 7.9 & 0.18 & 66 \\
\hline 26 & Monument Pond \#2 & 1.4 & 0.85 & 0.25 & 3.58 & 0.03 & 1.12 & 0.43 & 3.4 & 0.15 & 34 \\
\hline 27 & Town Brook \#1 & 2.1 & 0.61 & 0.2 & 3.67 & 0.06 & 0.97 & 0.38 & 5.3 & 0.18 & 54 \\
\hline 28 & Deleano Pond & 1.9 & 0.17 & 0.16 & 1.41 & 0.15 & 0.15 & 1.05 & 5.5 & 0.05 & 14 \\
\hline 29 & Worcester Consolidated Station & 1.9 & 1.05 & 0.42 & 5.25 & 0.12 & 1.77 & 0.84 & 5.6 & 0.23 & 49 \\
\hline 30 & Cooks Canyon Lower Pond & 2.8 & 1.65 & 0.33 & 6.12 & 0.18 & 1.67 & 1.67 & 5.3 & 0.35 & 46 \\
\hline 31 & Unnamed, Stony Brook & 1.3 & 0.79 & 0.37 & 3.64 & 0.1 & 0.79 & 1.11 & 4.5 & 0.17 & 49 \\
\hline 32 & Unnamed, Winnetuxet & 0.9 & 0.7 & 0.15 & 2.61 & 0.03 & 0.96 & 0.32 & 2.3 & 0.14 & 25 \\
\hline 1 & DUP-Factory Village Pond & 4 & 1.09 & 0.28 & 5.95 & 0.15 & 2.21 & 0.61 & 5.2 & 0.2 & 47 \\
\hline 13 & DUP-Mountain Lake & 2.2 & 1.51 & 0.56 & 6.37 & 0.1 & 1.65 & 1.34 & 8.1 & 0.3 & 70 \\
\hline 25 & DUP-Tel Electric Pond & 1.5 & 0.57 & 1.63 & 5.21 & 0.08 & 1.71 & 2.46 & 8 & 0.18 & 68 \\
\hline
\end{tabular}


Table 3. Concentrations of inorganic elements measured in bottom-sediment cores collected from selected impoundments in Massachusetts in 2004 and 2005.-Continued

[Concentrations were determined on unmilled samples using method 3050b digestion from U.S. Environmental Protection Agency (1996). DUP, field duplicate sample; no., number; ppm, parts per million; \%, percent; <, less than value shown]

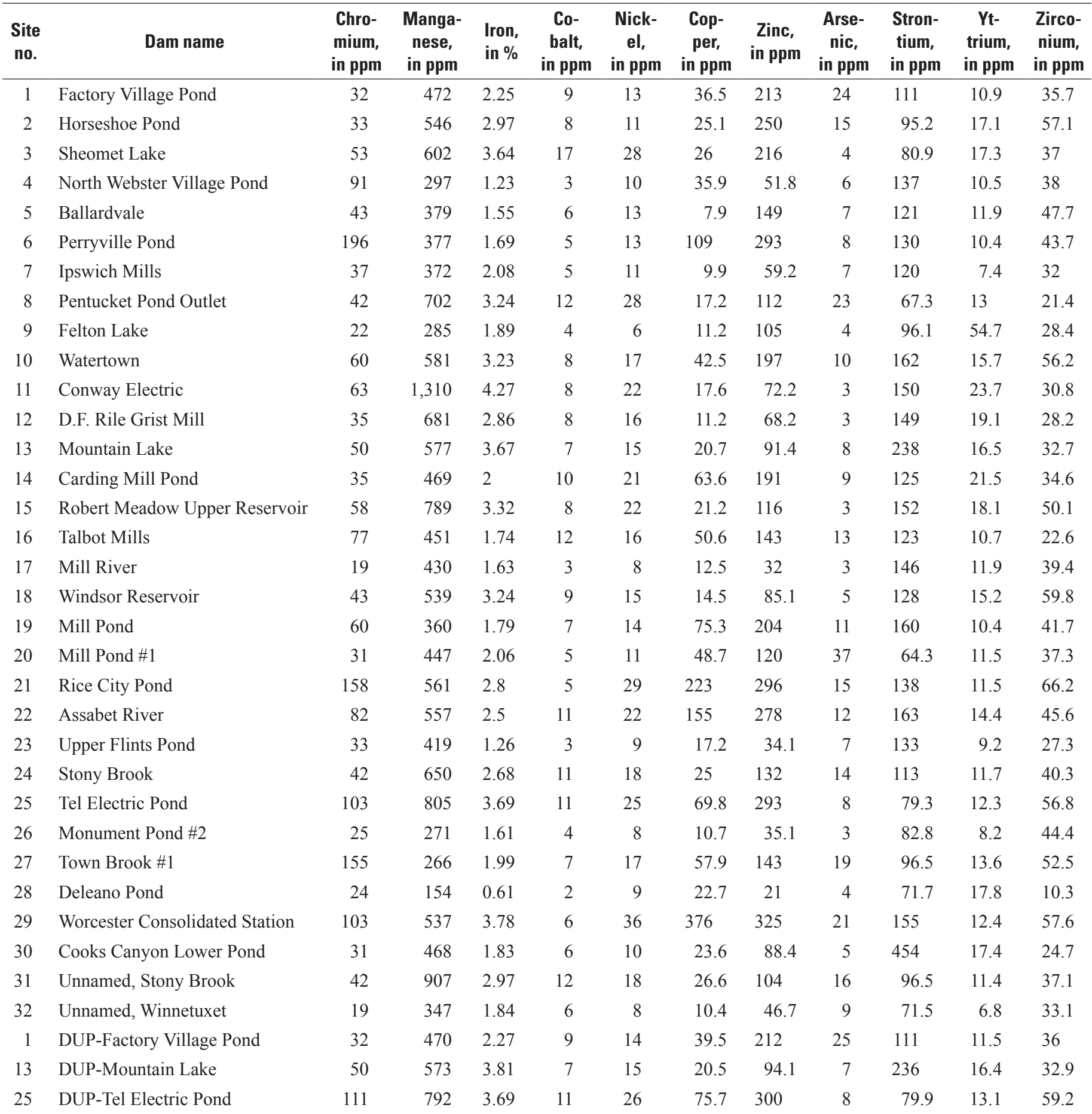


Table 3. Concentrations of inorganic elements measured in bottom-sediment cores collected from selected impoundments in Massachusetts in 2004 and 2005.-Continued

[Concentrations were determined on unmilled samples using method 3050b digestion from U.S. Environmental Protection Agency (1996). DUP, field duplicate sample; no., number; ppm, parts per million; \%, percent; <, less than value shown]

\begin{tabular}{|c|c|c|c|c|c|c|c|c|c|c|c|c|}
\hline $\begin{array}{l}\text { Site } \\
\text { no. }\end{array}$ & Dam name & $\begin{array}{l}\text { Molyb- } \\
\text { denum, } \\
\text { in ppm }\end{array}$ & $\begin{array}{l}\text { Silver, } \\
\text { in ppm }\end{array}$ & $\begin{array}{l}\text { Cad- } \\
\text { mium, } \\
\text { in ppm }\end{array}$ & $\begin{array}{l}\text { Tin, } \\
\text { in ppm }\end{array}$ & $\begin{array}{l}\text { Anti- } \\
\text { mony, } \\
\text { in ppm }\end{array}$ & $\begin{array}{l}\text { Bari- } \\
\text { um, } \\
\text { in ppm }\end{array}$ & $\begin{array}{c}\text { Lantha- } \\
\text { num, } \\
\text { in ppm }\end{array}$ & $\begin{array}{l}\text { Tung- } \\
\text { sten, } \\
\text { in ppm }\end{array}$ & $\begin{array}{c}\text { Lead, } \\
\text { in } \\
\text { ppm }\end{array}$ & $\begin{array}{c}\text { Bis- } \\
\text { muth, } \\
\text { in ppm }\end{array}$ & $\begin{array}{l}\text { Lithi- } \\
\text { um, } \\
\text { in ppm }\end{array}$ \\
\hline 1 & Factory Village Pond & $<1$ & $<2$ & 1 & 10 & $<5$ & 479 & 27.4 & $<10$ & 153 & $<5$ & 32 \\
\hline 2 & Horseshoe Pond & 2 & $<2$ & 2 & $<10$ & $<5$ & 321 & 25.6 & $<10$ & 49 & $<5$ & 11 \\
\hline 3 & Sheomet Lake & 2 & $<2$ & 2 & $<10$ & $<5$ & 336 & 24.6 & $<10$ & 46 & $<5$ & 24 \\
\hline 4 & North Webster Village Pond & $<1$ & $<2$ & $<1$ & 40 & $<5$ & 336 & 21.6 & $<10$ & 47 & $<5$ & 17 \\
\hline 5 & Ballardvale & $<1$ & $<2$ & $<1$ & $<10$ & $<5$ & 343 & 19.8 & $<10$ & 26 & $<5$ & 19 \\
\hline 6 & Perryville Pond & $<1$ & $<2$ & 1 & 20 & $<5$ & 323 & 20.3 & $<10$ & 104 & $<5$ & 18 \\
\hline 7 & Ipswich Mills & $<1$ & $<2$ & $<1$ & $<10$ & $<5$ & 346 & 14.6 & $<10$ & 32 & $<5$ & 18 \\
\hline 8 & Pentucket Pond Outlet & 2 & $<2$ & $<1$ & $<10$ & $<5$ & 143 & 17.2 & $<10$ & 13 & $<5$ & 13 \\
\hline 9 & Felton Lake & 1 & $<2$ & 2 & $<10$ & $<5$ & 327 & 60.8 & $<10$ & 29 & $<5$ & 16 \\
\hline 10 & Watertown & 2 & $<2$ & 4 & $<10$ & 7 & 440 & 24.7 & $<10$ & 142 & $<5$ & 16 \\
\hline 11 & Conway Electric & $<1$ & $<2$ & $<1$ & $<10$ & $<5$ & 363 & 24.8 & $<10$ & 20 & $<5$ & 40 \\
\hline 12 & D.F. Rile Grist Mill & $<1$ & $<2$ & $<1$ & $<10$ & $<5$ & 381 & 24.9 & $<10$ & 17 & $<5$ & 23 \\
\hline 13 & Mountain Lake & 1 & 5 & $<1$ & $<10$ & 6 & 582 & 43.7 & $<10$ & 82 & $<5$ & 14 \\
\hline 14 & Carding Mill Pond & 3 & $<2$ & 2 & $<10$ & $<5$ & 291 & 34.5 & $<10$ & 85 & $<5$ & 17 \\
\hline 15 & Robert Meadow Upper Reservoir & 1 & $<2$ & $<1$ & $<10$ & $<5$ & 404 & 35.3 & $<10$ & 37 & $<5$ & 59 \\
\hline 16 & Talbot Mills & 1 & $<2$ & $<1$ & $<10$ & $<5$ & 329 & 16.8 & $<10$ & 63 & $<5$ & 13 \\
\hline 17 & Mill River & $<1$ & $<2$ & $<1$ & $<10$ & $<5$ & 466 & 18.2 & $<10$ & 16 & $<5$ & 9 \\
\hline 18 & Windsor Reservoir & $<1$ & $<2$ & $<1$ & $<10$ & $<5$ & 501 & 31.1 & $<10$ & 16 & $<5$ & 19 \\
\hline 19 & Mill Pond & 2 & $<2$ & 19 & 20 & 20 & 531 & 26 & $<10$ & 205 & $<5$ & 30 \\
\hline 20 & Mill Pond \#1 & 2 & $<2$ & $<1$ & $<10$ & $<5$ & 304 & 18.7 & $<10$ & 93 & $<5$ & 10 \\
\hline 21 & Rice City Pond & 2 & 2 & 11 & 60 & $<5$ & 451 & 25.4 & 30 & 174 & $<5$ & 20 \\
\hline 22 & Assabet River & 2 & 2 & 1 & 20 & $<5$ & 438 & 27.6 & $<10$ & 110 & $<5$ & 25 \\
\hline 23 & Upper Flints Pond & 1 & $<2$ & $<1$ & $<10$ & $<5$ & 383 & 16.7 & $<10$ & 29 & $<5$ & 13 \\
\hline 24 & Stony Brook & 2 & $<2$ & $<1$ & $<10$ & $<5$ & 318 & 21.1 & $<10$ & 67 & $<5$ & 23 \\
\hline 25 & Tel Electric Pond & 1 & $<2$ & 1 & $<10$ & $<5$ & 420 & 25.9 & $<10$ & 241 & $<5$ & 36 \\
\hline 26 & Monument Pond \#2 & $<1$ & $<2$ & $<1$ & $<10$ & $<5$ & 329 & 14.1 & $<10$ & 15 & $<5$ & 13 \\
\hline 27 & Town Brook \#1 & 2 & $<2$ & $<1$ & 40 & $<5$ & 344 & 21.6 & $<10$ & 164 & $<5$ & 23 \\
\hline 28 & Deleano Pond & 4 & $<2$ & $<1$ & $<10$ & $<5$ & 77 & 23.2 & $<10$ & 18 & $<5$ & 5 \\
\hline 29 & Worcester Consolidated Station & 1 & $<2$ & 9 & 60 & 7 & 468 & 29.5 & $<10$ & 156 & $<5$ & 27 \\
\hline 30 & Cooks Canyon Lower Pond & $<1$ & $<2$ & $<1$ & $<10$ & $<5$ & 862 & 45.3 & $<10$ & 77 & $<5$ & 10 \\
\hline 31 & Unnamed, Stony Brook & 2 & $<2$ & $<1$ & $<10$ & $<5$ & 296 & 21.6 & $<10$ & 45 & $<5$ & 21 \\
\hline 32 & Unnamed, Winnetuxet & 2 & $<2$ & $<1$ & $<10$ & $<5$ & 307 & 13.2 & $<10$ & 18 & $<5$ & 9 \\
\hline 1 & DUP-Factory Village Pond & $<1$ & $<2$ & 1 & 10 & $<5$ & 442 & 29.5 & $<10$ & 156 & $<5$ & 32 \\
\hline 13 & DUP-Mountain Lake & 2 & 5 & $<1$ & $<10$ & $<5$ & 568 & 39.8 & $<10$ & 85 & $<5$ & 14 \\
\hline 25 & DUP-Tel Electric Pond & 1 & $<2$ & 1 & $<10$ & $<5$ & 398 & 26.3 & $<10$ & 257 & $<5$ & 37 \\
\hline
\end{tabular}




\section{Concentrations of Organic Compounds}

High concentrations of organic compounds in bottom sediment are generally the result of human activity, although some PAHs have natural sources (Van Metre and others, 2004). Of the 108 organic compounds tested in this study, 64 were measured in concentrations greater than the laboratory reporting level (table 4, in back of report). In general, the highest concentrations of organic compounds were measured at the Ballardvale Dam (site 5) on the Shawsheen River in Andover (table 4, in back of report). Almost half of the individual compounds detected were found at their highest concentration at this site [number $(n)$ of maximum concentrations $=26]$. The site with the second largest number of maximum concentrations $(n=10)$ was the Deleano Pond Dam (site 28). This result was unexpected. Deleano Pond drains a relatively small drainage area ( 0.3 square mile) with no commercial, industrial, or transportation land use and is presently within the Harold Parker State Forest in northeastern Massachusetts. The Deleano Pond Dam was built in the 1930s and may have had an industrial history that is not evident by information readily available from a geographic information system (GIS). High concentrations of individual organic compounds were also measured at the Tel Electric Pond Dam (site 25) and the Felton Lake Dam on the Housatonic River in Washington (site 9) compared with measurements at the other sampling locations.

The maximum concentrations for the three major groups of organic compounds considered in this study (total PAHs, total PCBs, and total DDTs) are also of interest (fig. 7; table 4, in back of report). The maximum concentration of total PAHs was found at the Ballardvale Dam (site 5) where individual compounds were also present at elevated concentrations. The maximum concentration of total PCBs was found at the Mill Pond Dam (site 19; estimated value), and the maximum concentration of total DDTs was found at the Stony Brook Dam in Lincoln (site 24).

The major groups of compounds differed in their frequency of detection. Total PAHs were found most frequently, with detections at all 32 sites (100 percent of sites). Total PCBs were the least widespread, with detections at only 10 of the sites (31 percent). Total DDTs were found at 29 of the sites (91 percent), a detection frequency between that of the other two groups. The relatively high rate of detection for total PAHs (69 percent of sites) suggests a potential likelihood of nonpoint sources of total PAHs in the contributing watersheds to the impoundments. The potential role of nonpoint sources of PAHs to impoundments is supported by recent research on sources of PAHs to the lakes and reservoirs of the United States (Van Metre and others, 2010). By contrast, the lower rate of detection for total PCBs (31 percent of sites) suggests that point sources may play an important role at sites where PCBs were detected during the present study. Recent research in Massachusetts (Breault and others, 2004) has provided sitespecific information on the role of $\mathrm{PCB}$ point sources in the contamination of impounded sediment.

\section{Estimated Toxicity of Sediments}

Although concentrations of priority pollutants may be used to help prioritize dam removal projects, contaminant concentrations alone do not indicate the potential risk posed by toxic contaminants. Potential toxicity of sediments to benthic organisms may be estimated by comparing observed contaminant concentrations in sediment to widely accepted criteria such as threshold effects concentrations (TECs) and probable effects concentrations (PECs; MacDonald and others, 2000). The TECs and PECs for each of the contaminants considered in this study (inorganic elements and organic compound groups) are shown on figures 6 and 7.

Among the inorganic elements, lead exceeded the PEC most frequently, with 7 of 32 impoundments ( 22 percent) having average lead concentrations above the PEC. Cadmium, chromium, and copper each exceeded the PEC at three impoundments ( 9 percent of sites), and arsenic exceeded the $\mathrm{PEC}$ at one impoundment. The remaining inorganic elements (nickel and zinc) did not exceed their PECs at any of the impoundments. Among the organic compound groups, total PAHs, total PCBs, and total DDTs exceeded the PEC at three, two, and zero sites, respectively.

The overall sediment toxicity at each of the impoundments was estimated by calculating the average $P E C Q_{x}$ for a sample (MacDonald and others (2000). The $P E C Q_{x}$ values (table 5) are used to assign an overall likelihood of toxicity (in percent) to each sediment sample (table 6). These likelihood values serve as indicators of the potential risk posed by the sediment to local and downstream receptors.

The likelihood of toxicity ranged from 8 to 70 percent among the sampling locations, and averaged 28 percent. A likelihood value of 28 percent means that 28 out of 100 toxicity tests are likely to show some level of toxicity for a given sample. Values greater than 60 percent were obtained for 3 of the 32 sites: Mill Pond Dam (site 19), Rice City Pond Dam (site 21), and Worcester Consolidated Station Dam (site 2). Cadmium was the largest single contributor to the estimated sediment toxicity at the two sites with the highest overall toxicity (Mill Pond Dam and Rice City Pond Dam; table 5). although total PCBs were also a large contributor to toxicity at the Mill Pond Dam. Copper was the largest contributor to toxicity at the Worcester Consolidated Station Dam, the site with the third highest overall toxicity. The Ballardville Dam (site 5) was the site where toxicity was most strongly dominated by a single contaminant - in this case, total PAHs, which contributed 70 percent of the overall toxicity. Chromium was a widespread contaminant; it contributed the largest single fraction of toxicity at 11 of the 32 sites, including not only sites with relatively low overall toxicity [Mill River Dam on the Mill River in Taunton (site 17) and Monument Pond \#2 Dam on the Assonet River in Freetown (site 26)], but also sites with relatively high overall toxicity [Perryville Pond Dam (site 6) and Town Brook \#1 Dam on the Town Brook in Plymouth (site 27)]. 

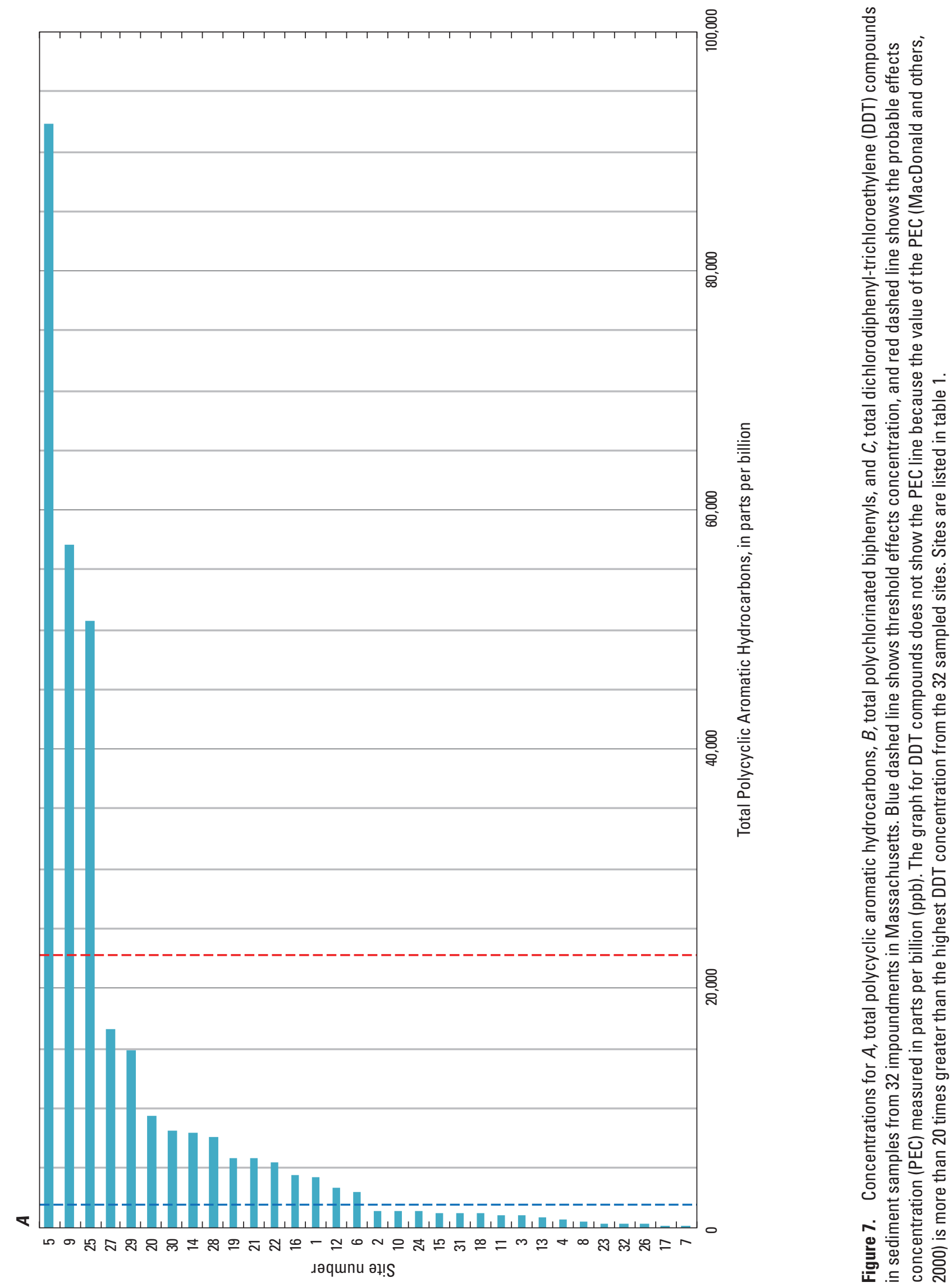


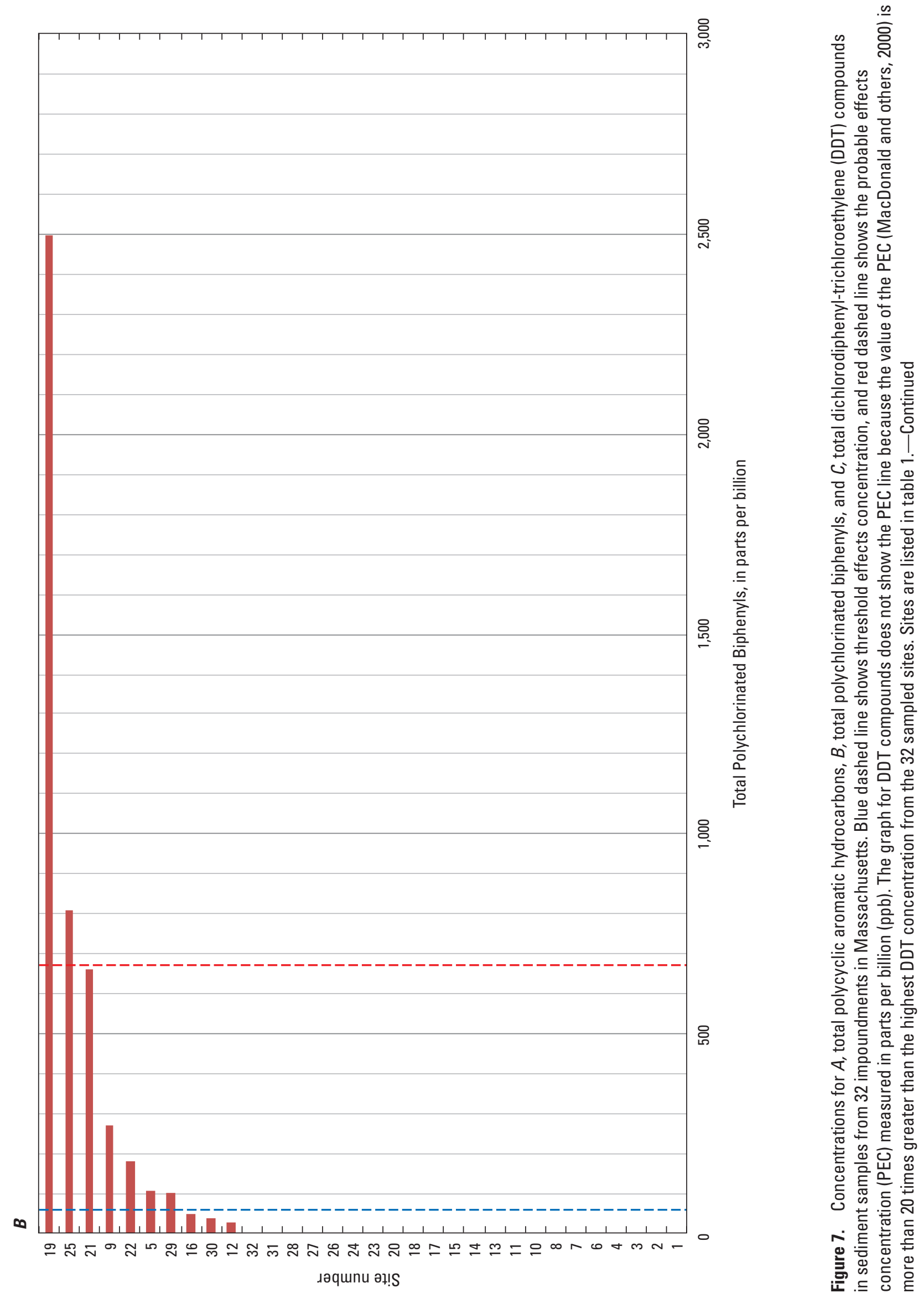



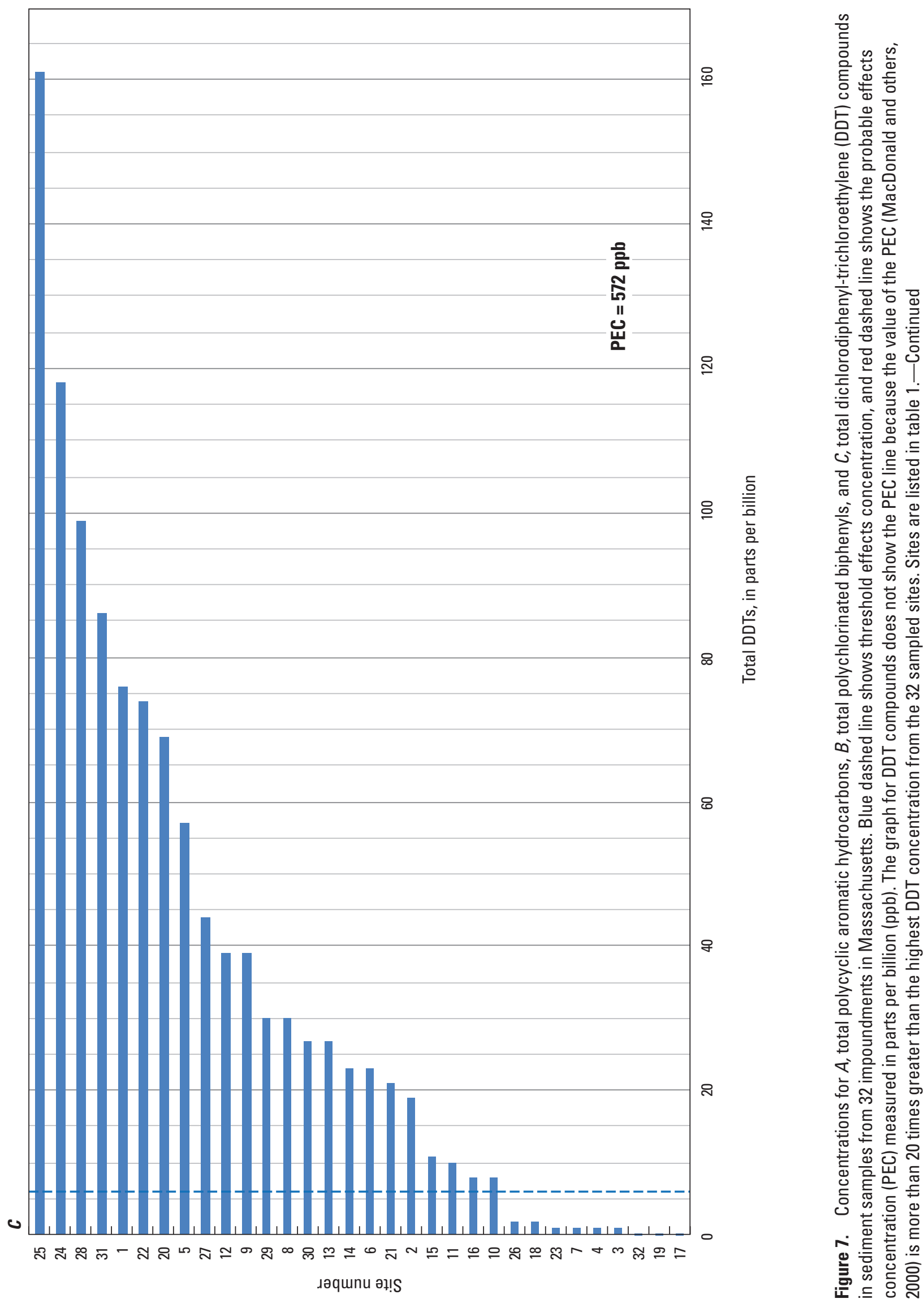


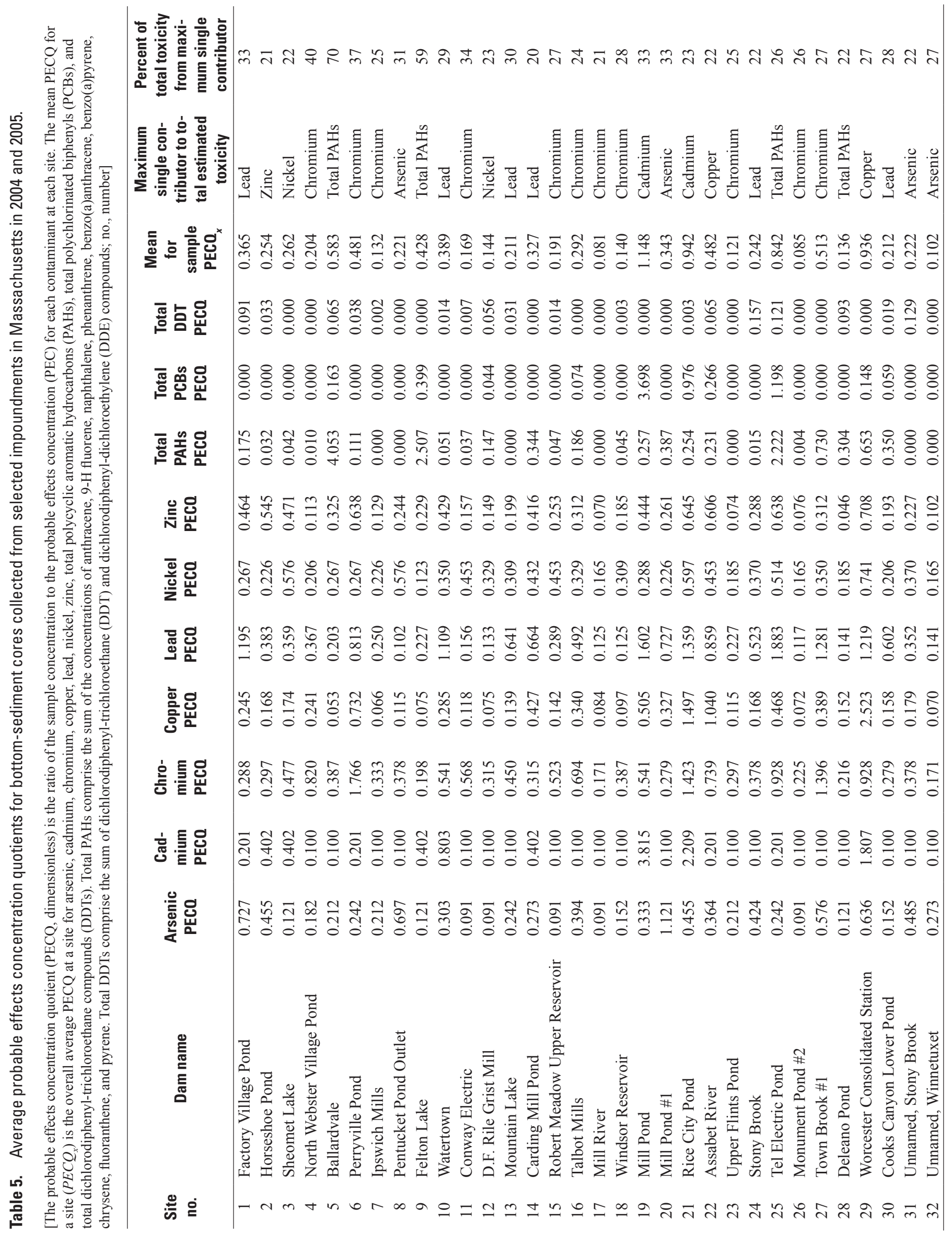


Table 6. Likelihood of toxicity of bottom-sediment cores collected from selected impoundments in Massachusetts in 2004 and 2005.

[Likelihoood of toxicity calculated from equation 2 of this report (MacDonald and others, 2000). The average probable effects concentration quotient for a site $\left(P E C Q_{x}\right)$ is the average of the PECQs for arsenic, cadmium, chromium, copper, lead, nickel, and zinc, total polycyclic aromatic hydrocarbons (PAHs), total polychlorinated biphenyls (PCBs), and total dichlorodiphenyl-trichloroethylene (DDTs). For the purposes of this report, total DDTs comprise the sum of dichlorodiphenyl-trichloroethane and dichlorodiphenyl-dichloroethylene compounds. Total PAHs comprise the sum of the concentrations of anthracene, 9H-fluorene, naphthalene, phenanthrene, benzo(a)anthracene, benzo(a)pyrene, chrysene, fluoranthene, and pyrene. no., number]

\begin{tabular}{|c|c|c|c|}
\hline Site no. & Dam name & $\begin{array}{l}\text { Mean } \\
\text { PECO }\end{array}$ & $\begin{array}{c}\text { Estimated likelihood of toxicity } \\
\text { of bottom-sediment cores, } \\
\text { in percent }\end{array}$ \\
\hline 1 & Factory Village Pond & 0.365 & 32 \\
\hline 2 & Horseshoe Pond & 0.254 & 23 \\
\hline 3 & Sheomet Lake & 0.262 & 24 \\
\hline 4 & North Webster Village Pond & 0.204 & 19 \\
\hline 5 & Ballardvale & 0.583 & 46 \\
\hline 6 & Perryville Pond & 0.481 & 39 \\
\hline 7 & Ipswich Mills & 0.132 & 13 \\
\hline 8 & Pentucket Pond Outlet & 0.221 & 21 \\
\hline 9 & Felton Lake & 0.428 & 36 \\
\hline 10 & Watertown & 0.389 & 33 \\
\hline 11 & Conway Electric & 0.169 & 16 \\
\hline 12 & D.F. Rile Grist Mill & 0.144 & 14 \\
\hline 13 & Mountain Lake & 0.211 & 20 \\
\hline 14 & Carding Mill Pond & 0.327 & 29 \\
\hline 15 & Robert Meadow Upper Reservoir & 0.191 & 18 \\
\hline 16 & Talbot Mills & 0.292 & 26 \\
\hline 17 & Mill River & 0.081 & 8 \\
\hline 18 & Windsor Reservoir & 0.140 & 14 \\
\hline 19 & Mill Pond & 1.148 & 70 \\
\hline 20 & Mill Pond \#1 & 0.343 & 30 \\
\hline 21 & Rice City Pond & 0.942 & 63 \\
\hline 22 & Assabet River & 0.482 & 39 \\
\hline 23 & Upper Flints Pond & 0.121 & 12 \\
\hline 24 & Stony Brook & 0.242 & 22 \\
\hline 25 & Tel Electric Pond & 0.842 & 59 \\
\hline 26 & Monument Pond \#2 & 0.085 & 8 \\
\hline 27 & Town Brook \#1 & 0.513 & 41 \\
\hline 28 & Deleano Pond & 0.136 & 13 \\
\hline 29 & Worcester Consolidated Station & 0.936 & 62 \\
\hline 30 & Cooks Canyon Lower Pond & 0.212 & 20 \\
\hline 31 & Unnamed, Stony Brook & 0.222 & 21 \\
\hline 32 & Unnamed, Winnetuxet & 0.102 & 10 \\
\hline
\end{tabular}


This evaluation of potential toxicity was intended to distinguish contaminants or contaminant groups that are likely to be associated with adverse biological effects at specific sampling locations. Additionally, these data were calculated for homogenized core samples and may not represent potential toxicity at the present day sediment surface (top 4 inches) where many benthic organisms live and feed. Nevertheless, estimated toxicity values can be used to help evaluate the relative ecological risks present in the studied impoundments.

\section{Relations Among Contaminant Concentrations, Land Use, and Industrial History}

Present day land use has been shown to be an accurate predictor of shallow sediment chemistry in certain situations. For example, Chalmers and others (2007, figs. 2 and 3 ) showed that the percentage of commercial, industrial, and transportation (CIT) land use in a drainage basin can be used to predict concentrations of both individual contaminant concentrations and average PECQs for lake and impoundment sediment accumulated since 1990 in New England. However, predicting potential risk to biota posed by toxic contaminants buried at deeper levels within sediment_representing pointand nonpoint-source contamination from activities in the drainage basin many decades in the past - has not been tested using this approach.

Correlation analysis was conducted to evaluate relations between basin characteristics and sediment contaminant concentrations, following the approach of Chalmers and others (2007). Concentrations of individual inorganic elements and organic compound groups (total PAHs, total PCBs, and total DDTs) were used as response variables. The explanatory variables tested were obtained from publicly available geospatial data layers, and included the drainage basin area upstream of each dam, the number of upstream dams, the percentage of impervious area, the percentage of commercial, industrial, and transportation land use in the basin in 1971 and 2005, and the number of $21 \mathrm{E}^{1}$ sites (Massachusetts Office of Geographic and Environmental Information, 2009). In addition, the number of factories operating in the 1830s in each drainage basin was obtained from a recent geospatial compilation of historical information (Hall and others, 2002). Information concerning land use in 1971 and the number of factories operating in each drainage basin in the 1830s was included in the analysis (table 7) to represent conditions prior to the effects of the U.S. Clean Water Act, enacted in 1972 (U.S. Environmental Protection Agency, 2011).

\footnotetext{
${ }^{1}$ Sites noted as $21 \mathrm{E}$ sites are oil and (or) hazardous material disposal sites that have been reported and classified under Massachusetts General Laws chapter 21E (General Court of the Commonwealth of Massachusetts, undated) and the Massachusetts Contingency Plan (310 CMR 40.0000; Massachusetts Department of Environmental Protection, undated).
}

Correlations between several of the response variables and particular explanatory, or landscape, variables were found to be statistically significant ( $p$ values less than 0.05 ) or highly significant ( $p$ less than 0.01 ; table 8 ). The landscape variable with the largest number of significant correlations with contaminant concentrations was the number of factories in each drainage area in the 1830 s. Concentrations of five of the inorganic elements (chromium, copper, zinc, cadmium, lead) as well as total PAH concentrations were significantly correlated with this variable. Three other landscape variables (number of dams, commercial and industrial land use in 1971, and number of $21 \mathrm{E}$ sites) were found to be significantly correlated with inorganic metal concentrations, with each landscape variable showing significant correlations with a different subset of inorganic elements (table 8). One of the inorganic elements (arsenic) and two of the groups of organic compounds (total PCBs and total DDTs) showed no significant correlations with any of the landscape variables.

Other statistical approaches (univariate, multivariate, and logistic regression modeling with and without transformations of variables) were also tested to predict contaminant concentrations and toxicity potential. Numerous individual correlations between chemical concentrations and present day landscape variables were found to be statistically significant (as described above). However, none of the regression models described a sufficient amount of the overall variability to make the models useful for prediction of the depth-averaged, bulk sediment concentration at unsampled impoundments in Massachusetts. These findings suggest that human activities in Massachusetts drainage basins have varied to such an extent during the past 200 years that it may not be feasible to predict the depth-averaged quality of impounded sediment behind most unsampled impoundments, using models based largely on recent land use in the contributing drainage basin. If the objective of a particular investigation is to predict the chemical quality and potential toxicity of recently deposited (post-1990) sediment behind a dam in Massachusetts, existing models relating chemistry and potential toxicity to geospatial indicators of urbanization in New England (for example, Chalmers and others, 2007) may be sufficient for screening purposes. However, if the objective is to characterize average sediment quality and potential toxicity over the entire range of sediment depths, the results of this study suggest that sitespecific sampling will likely be required.

The data collected and interpreted for this study could provide a starting point for a statewide database of information concerning Massachusetts impoundments. Such a database could include data on impoundment water depths (bathymetry), impounded sediment thicknesses, sediment chemical quality, and potential toxicity of sediment to benthic organisms. This information could be used to help prioritize sites for dam removal, and to inform impounded sediment management decisions in the Commonwealth. 


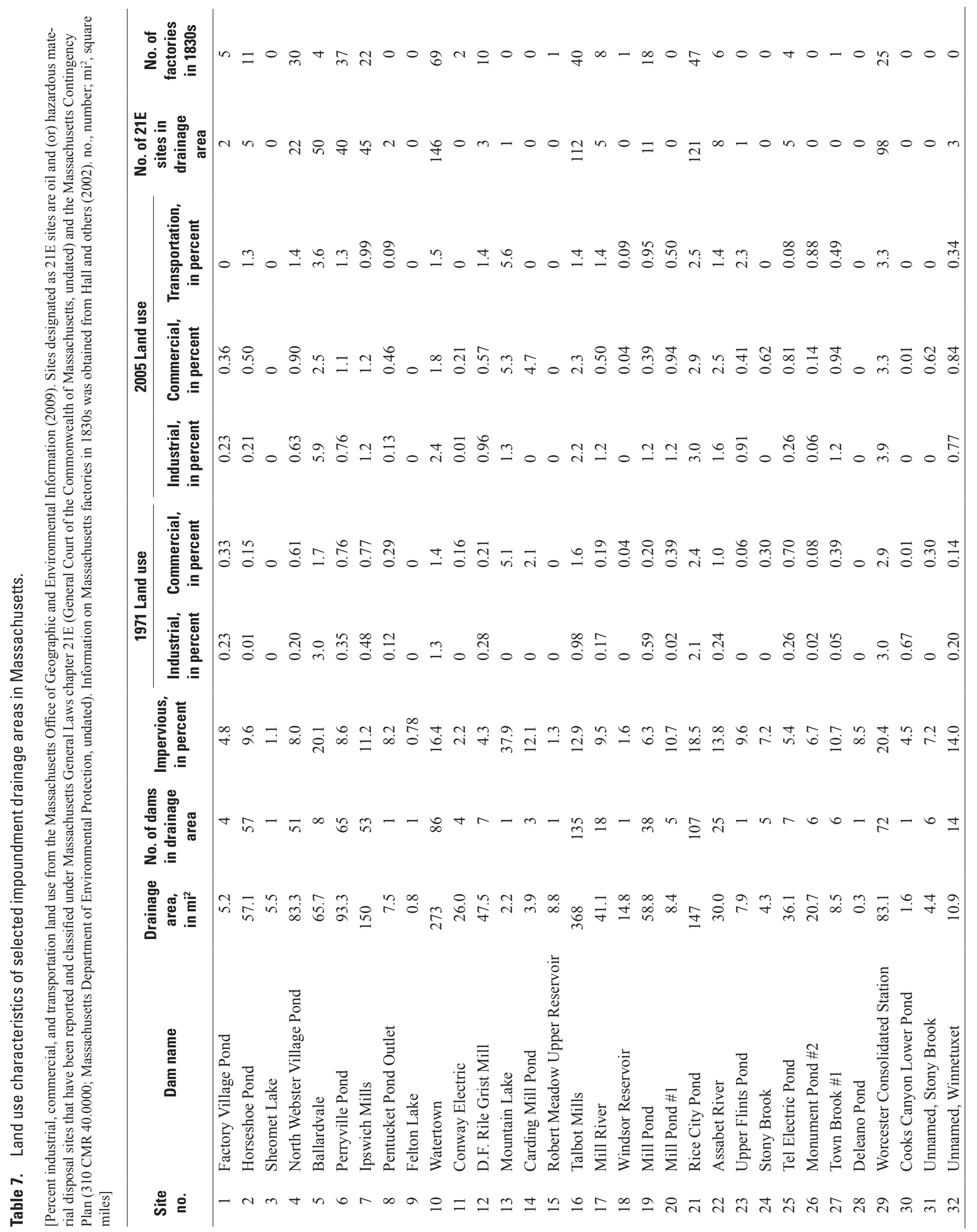


Table 8. Relations between sediment-core contaminant concentrations and land use in the drainage areas of selected impoundments in Massachusetts.

[CIT 2005 is the sum of commercial, industrial, and transportation land use for 2005; CI 1971 is the sum of commercial and industrial land use for 1971. Number of 21E sites is the number of oil and (or) hazardous material disposal sites that have been reported and classified under Massachusetts General Laws chapter $21 \mathrm{E}$ and the Massachusetts Contingency Plan. $r$ is the Pearson's correlation coefficient. $p$ value, a measure of statistical significance; $p$ values less than 0.05 are considered significant and are in bold type. The number of factories in 1830s was obtained from Hall and others (2002); all other information was obtained from the Massachusetts Office of Geographic and Environmental Information (2009). DDT, dichlorodiphenyl-trichloroethane; PAH, polycyclic aromatic hydrocarbon; PCB, polychlorinated biphenyl]

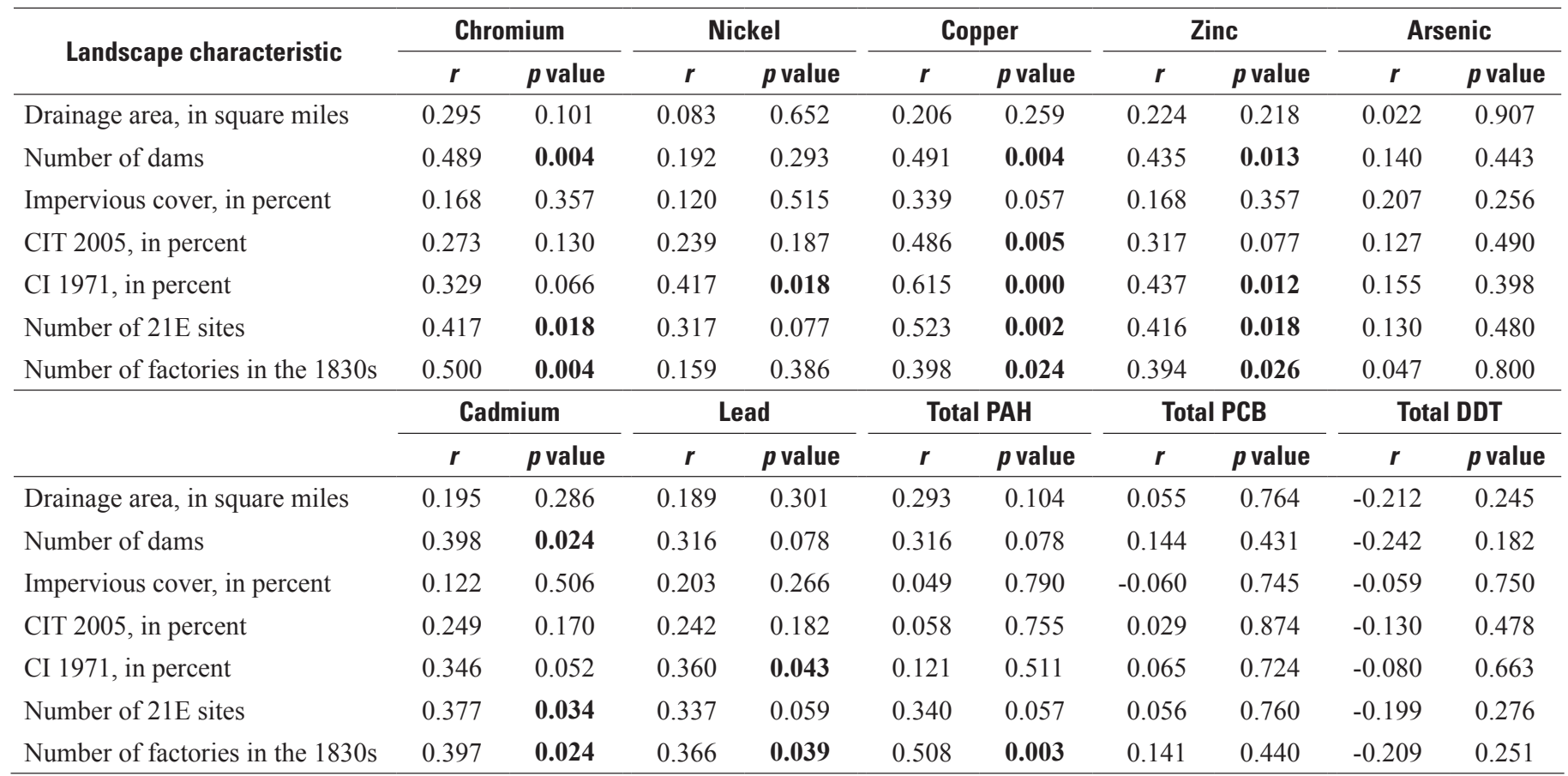




\section{Summary}

Contaminants in impounded sediment may be a source of contaminants to the overlying water column, to organisms that live on or in bottom sediment, and to wildlife and humans that come into contact with contaminated sediment. Such sediment may also be an ongoing source for resuspension, downstream transport, and dispersal of contaminants. The U.S. Geological Survey and the Massachusetts Department of Fish and Game, Division of Ecological Restoration collaborated to collect baseline information describing the thickness of impounded sediment and the concentrations of sediment-associated contaminants behind 32 dams throughout Massachusetts. Sediment-core samples were collected, and concentrations of 32 inorganic elements and 108 organic compounds were quantified.

Sediment thicknesses across the 32 impoundments ranged from 0 to more than 20 feet and averaged 3.7 feet. Bottom-sediment volumes - estimated by multiplying the average sediment thickness by impoundment surface area-ranged from about 55,000 cubic feet to 81 million cubic feet. Concentrations of contaminants toxic to benthic organisms, as well as the number detected above laboratory reporting levels, varied greatly among sampling locations. Of the impoundments sampled, the highest concentrations of inorganic elements and organic compounds generally were measured in samples collected from impoundments downstream of present or former urban and industrial areas, including the Blackstone and North Nashua Rivers (elements) and the Shawsheen River (organic compounds). The estimated probability of toxicity of bottom sediment ranged from about 8 to 70 percent among the sampling locations and averaged slightly under 30 percent. Statistically significant correlations ( $p$ less than 0.05) were found between concentrations of some of the contaminants and upstream basin characteristics. In particular, significant correlations were found between the number of factories operating in each drainage basin in the 1830 s and the concentrations of several inorganic elements (cadmium, chromium, copper, lead, and zinc) as well as total PAH concentrations. However, predictive statistical models developed from the data were found to have a high degree of uncertainty. This result is consistent with the complex industrial history to which impoundments in Massachusetts have typically been subjected over their periods of deposition. This result also indicates that site-specific sampling may likely be required to characterize overall, depth-averaged sediment quality at unsampled impoundments in Massachusetts.

\section{References Cited}

Armstrong, D.S., Richards, T.A., and Levin, S.B., 2011, Factors influencing riverine fish assemblages in Massachusetts: U.S. Geological Survey Scientific Investigations Report 2011-5193, 58 p. (Also available at http://pubs.usgs.gov/ sir/2011/5193.)

Breault, R.F., Cooke, M.G., and Merrill, Michael, 2004, Sediment quality and polychlorinated biphenyls in the lower Neponset River, Massachusetts, and implications for urban river restoration: U.S. Geological Survey Scientific Investigations Report 2004-5109, 48 p. (Also available at http://pubs.usgs.gov/sir/2004/5109/.)

Breault, R.F., Durant, J.L., and Robbat, Albert, Jr., 2005, Sediment quality of lakes, rivers, and estuaries in the Mystic River Basin, eastern Massachusetts, 2001-03: U.S. Geological Survey Scientific Investigations Report 2005-5191, 110 p. (Also available at http://pubs.usgs.gov/ $\operatorname{sir} / 2005 / 5191 /$.)

Breault, R.F., Reisig, K.R., Barlow, L.K., and Weiskel, P.K., 2000, Distribution and potential for adverse biological effects of inorganic elements and organic compounds in bottom sediment, lower Charles River, Massachusetts: U.S. Geological Survey Water-Resources Investigations Report 2000-4180, $70 \mathrm{p}$.

Brown, R.D., and Tager, Jack, 2000, Massachusetts-A concise history: Amherst, Mass., University of Massachusetts Press, $361 \mathrm{p}$.

Chalmers, A.T., Van Metre, P.C., and Callender, E., 2007, The chemical response of particle-associated contaminants in aquatic sediments to urbanization in New England, U.S.A.: Journal of Contaminant Hydrology, v. 91, no. 1-2, April, p. 4-25.

Childress, C.J.O., Foreman, W.T., Connor, B.F., and Maloney, T.J., 1999, New reporting procedures based on long-term method detection levels and some considerations for interpretations of water-quality data provided by the U.S. Geological Survey National Water Quality Laboratory: U.S. Geological Survey Open-File Report 99-193, 19 p.

Foreman, W.T., Connor, B.F., Furlong, E.T., Vaught, D.G., and Merten, L.M., 1995, Methods of analysis by the U.S. Geological Survey National Water Quality Laboratory; determination of organochlorine pesticides and polychlorinated biphenyls in bottom sediment by dual capillary-column gas chromatography with electron-capture detection: U.S. Geological Survey Open-File Report 95-140, 78 p. 
Furlong, E.T., Vaught, D.G., Merten, L.M., Foreman, W.T., and Gates, P.M., 1996, Methods of analysis by the U.S. Geological Survey National Water Quality Laboratory; determination of semivolatile organic compounds in bottom sediment by solvent extraction, gel permeation chromatographic fractionation, and capillary-column gas chromatography/mass spectrometry: U.S. Geological Survey OpenFile Report 95-719, 67 p.

Gardner, C., Coghlan, S.M., Zydlewski, J., and Saunders, R., 2011, Distribution and abundance of stream fishes in relation to barriers: Implications for monitoring stream recovery after barrier removal: River Research and Applications, August 22, accessed December 18, 2012, at http://digitalcommons.unl.edu/cgi/viewcontent.cgi?article=1 267\& context $=$ usdeptcommercepub.

General Court of the Commonwealth of Massachusetts, [undated], Massachusetts oil and hazardous material release prevention and response act, chap. 21E of General laws part I title II: The 187th General Court of the Commonwealth of Massachusetts, accessed February 8, 2012, at http://www.malegislature.gov/Laws/GeneralLaws/PartI/ TitleII/Chapter21E.

Graf, W.L., 1999, Dam nation-A geographic census of American dams and their large-scale hydrologic impacts: Water Resources Research, v. 35, no. 4, April, p. 13051311. (Also available at http://www.wou.edu/las/physci/ taylor/g407/graf_1999.pdf.)

Hall, Brian, Motzkin, Glenn, Foster, D.R., Syfert, Mindy, and Burk, John, 2002, Three hundred years of forest and land-use change in Massachusetts, U.S.A.: Journal of Biogeography, v. 29, p. 1319-1335. (Also available at http:/hfr.lternet.edu/sites/harvardforest.fas.harvard.edu/ files/publications/pdfs/Hall_JBiogeography_2002.pdf.)

Ingersoll, C.G., MacDonald, D.D., Wang, Ning, Crane, J.L., Field, L.J., Haverland, P.S., Kemble, N.E., Lindskoog, R.A., Severn, Corinne, and Smorong, D.E., 2000, Predictions of sediment toxicity using consensus-based freshwater sediment quality guidelines: U.S. Environmental Protection Agency EPA 905/R-00/007, June, 25 p., plus figures, tables, and appendix, accessed February 2, 2012, at http://www.cerc.usgs.gov/pubs/center/pdfdocs/91126.pdf.

MacDonald, D.D., Ingersoll, C.G., and Berger, T.A., 2000, Development and evaluation of consensus-based sediment quality guidelines for freshwater ecosystems: Archives of Environmental Contamination and Toxicology, v. 39, p. 20-31, accessed February 2, 2012, at http://www.swrcb. ca.gov/water_issues/programs/tmdl/docs/303d_policydocs/241.pdf.
Massachusetts Department of Environmental Protection, [undated], 310 CMR 40.0000-Massachusetts contingency plan: Massachusetts Department of Environmental Protection, accessed February 8, 2012, at http:/www.mass.gov/ dep/cleanup/laws/mcptoc.htm.

Massachusetts Office of Geographic and Environmental Information, 2009, Land use datalayers for 2005 and 1971: Massachusetts Office of Geographic and Environmental Information, accessed February 2, 2012, at http://www.mass.gov/mgis/database.htm.

Noriega, M.C., Wydoski, D.S., and Foreman, W.T., 2004, Methods of analysis by the U.S. Geological Survey National Water Quality Laboratory-Determination of organochlorine pesticides and polychlorinated biphenyls in bottom and suspended sediment by gas chromatography with electroncapture detection: U.S. Geological Survey Water-Resources Investigations Report 2003-4293, 46 p. (Also available at http://nwql.usgs.gov/pubs/WRIR/WRIR-03-4293.pdf.)

Poff, N.L., and Hart, D.D., 2002, How dams vary and why it matters for the emerging science of dam removal: BioScience, v. 52, no. 8, p. 659-668.

U.S. Army Corps of Engineers, 1996, Water control infrastructure: U.S. Army Corps of Engineers National Inventory of Dams, on CD-ROM.

U.S. Environmental Protection Agency, 1996, Method 3050B - Acid digestion of sediments, sludges, and soils (revision 2): U.S. Environmental Protection Agency, 12 p., accessed February 8, 2012, at http:/www.epa.gov/wastes/ hazard/testmethods/sw846/pdfs/3050b.pdf.

U.S. Environmental Protection Agency, 2011, Clean Water Act: U.S. Environmental Protection Agency, accessed February 8, 2012, at http://cfpub.epa.gov/npdes/ cwa.cfm?program_id $=45$.

U.S. Environmental Protection Agency, [undated], Priority pollutants: U.S. Environmental Protection Agency, accessed February 7, 2012, at http://www.epa.gov/waterscience/ methods/pollutants.htm.

Van Metre, P.C., and Mahler, B.J., 2010, Contribution of PAHs from coal-tar pavement sealcoat and other sources to 40 U.S. lakes: Science of the Total Environment, v. 409, no. 2, December 15, p. 334-344.

Van Metre, P.C., Wilson, J.T., Fuller, C.C., Callender, Edward, and Mahler, B.J., 2004, Collection, analysis, and agedating of sediment cores from 56 U.S. lakes and reservoirs sampled by the U.S. Geological Survey, 1992-2001: U.S. Geological Survey Scientific Investigations Report 2004-5184, 187 p. (Also available at http://pubs.usgs.gov/ sir/2004/5184/.) 
Wang, Lizhu, Infante, Dana, Lyons, John, Stewart, Jana, and Cooper, Arthur, 2010, Effects of dams in river networks on fish assemblages in non-impoundment sections of rivers in Michigan and Wisconsin, U.S.A.: River Research and Applications, v. 27, no. 4, p. 473-487, accessed December 10, 2010, at http://onlinelibrary.wiley.com/doi/10.1002/ rra.1356/abstract.

Zimmerman, M.J., and Breault, R.F., 2003, Sediment quantity and quality in three impoundments in Massachusetts: U.S. Geological Survey Water-Resources Investigations Report 03-4017, $36 \mathrm{p}$.

Zimmerman, M.J., and Sorenson, J.R., 2005, Sediment studies in the Assabet River, central Massachusetts, 2003: U.S. Geological Survey Scientific Investigations Report 2005$5131,87 \mathrm{p}$. 
Table $4 \quad 31$

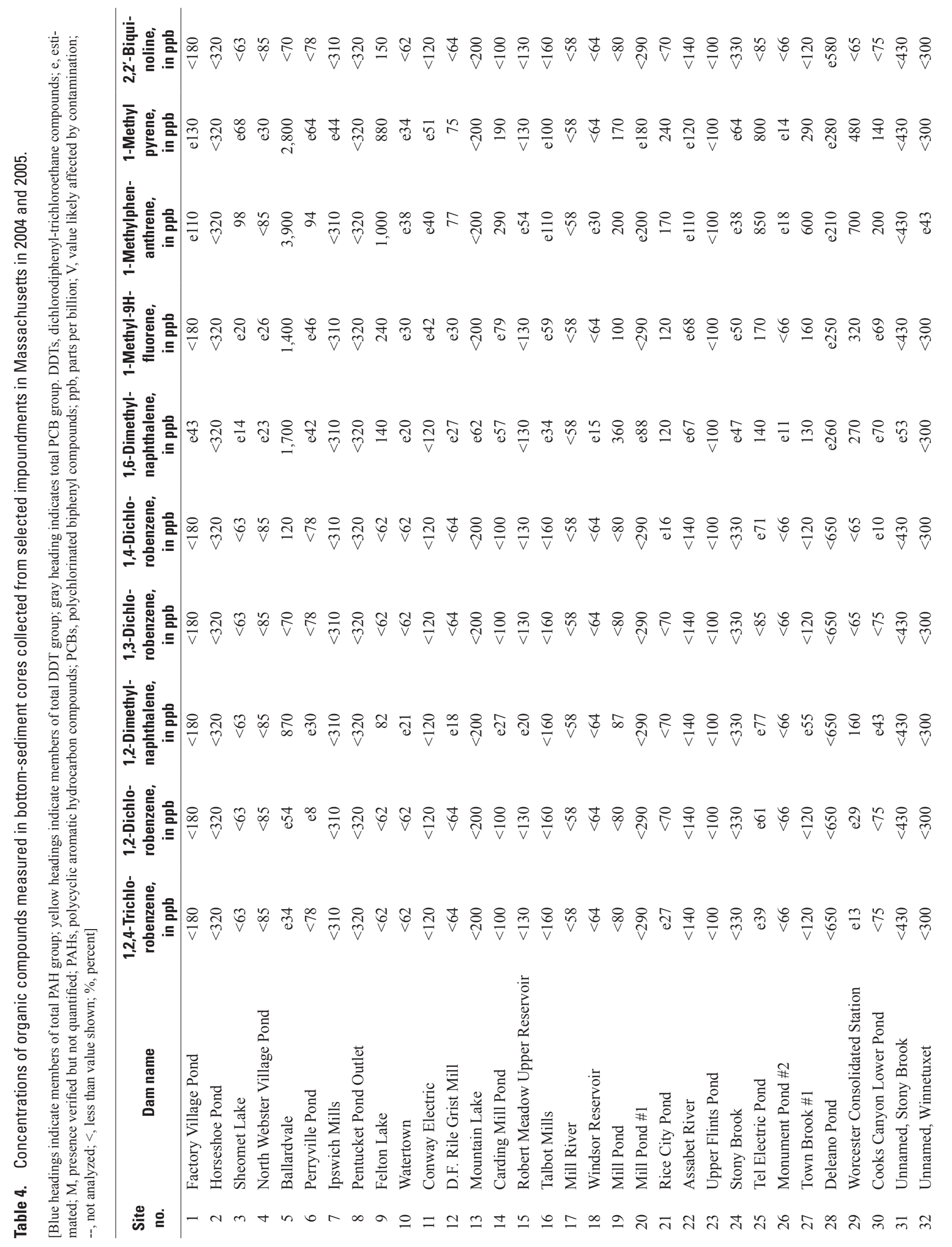




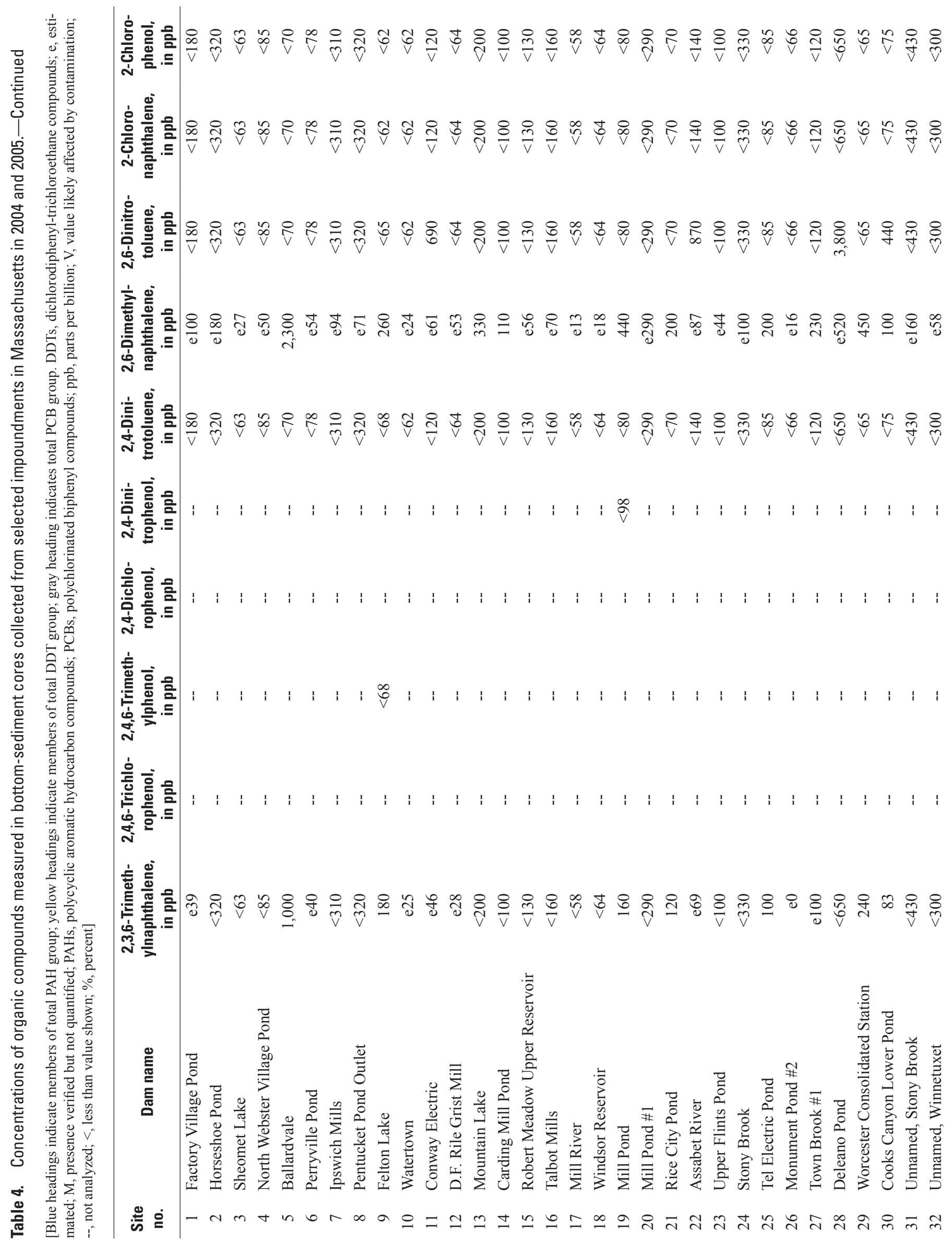




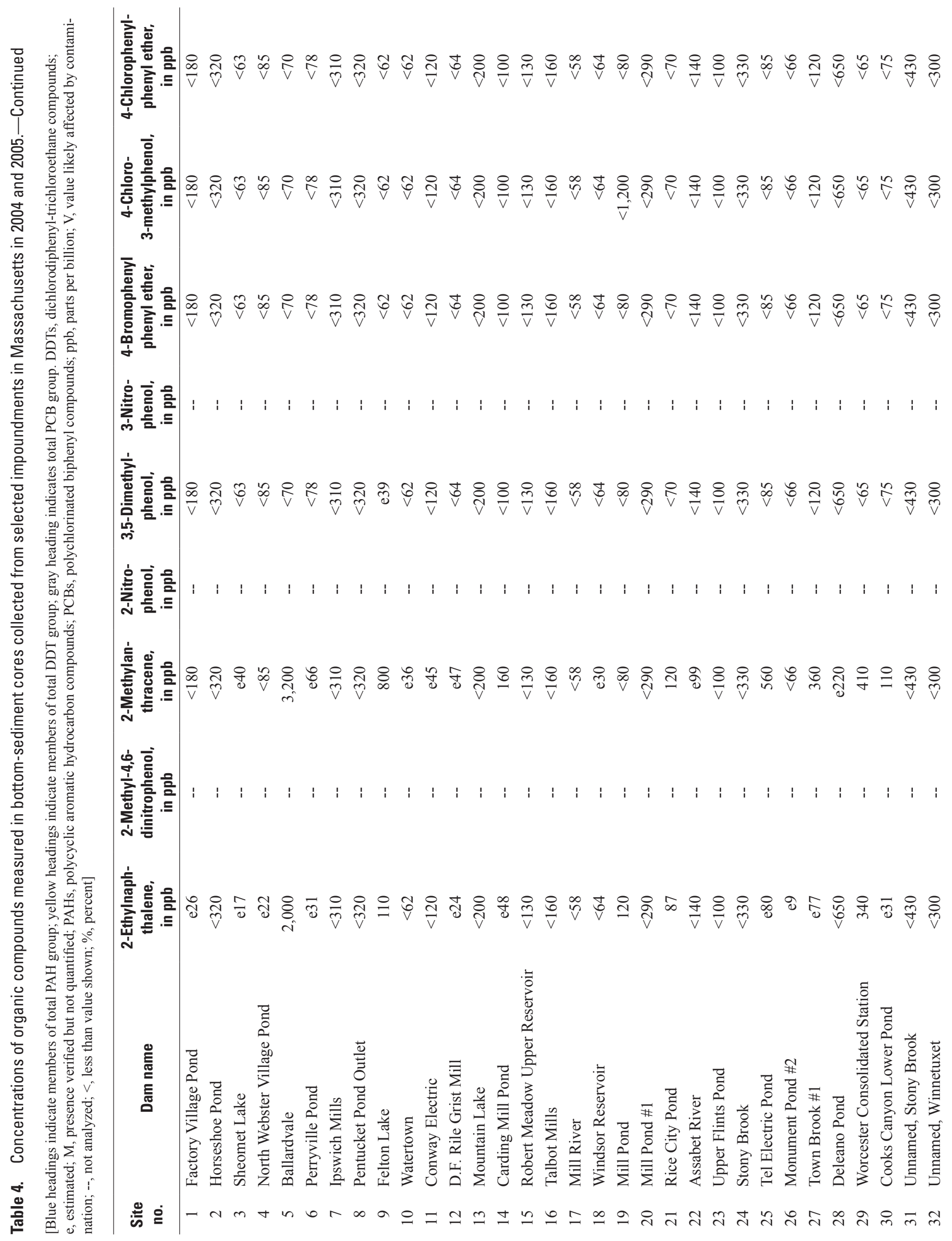




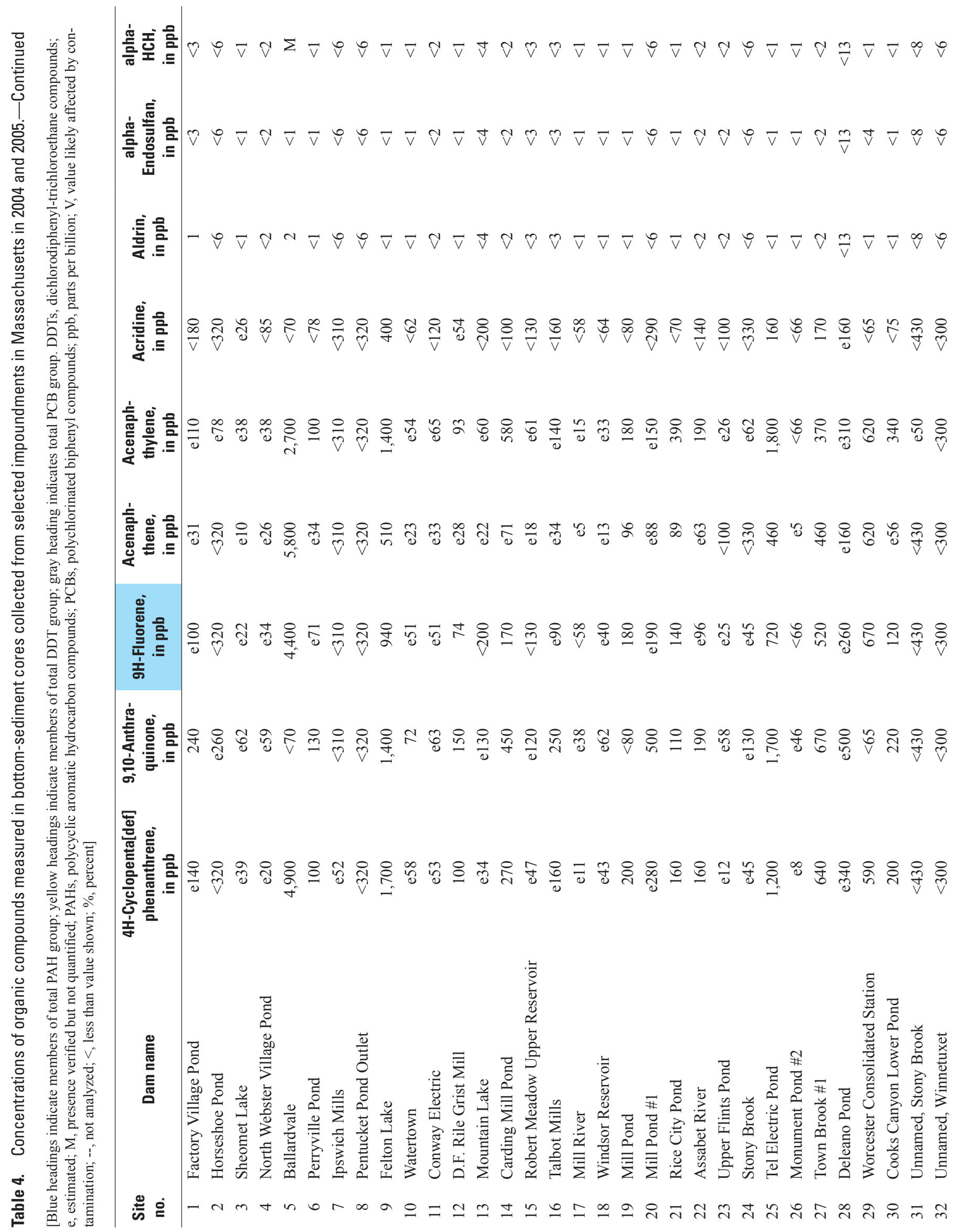




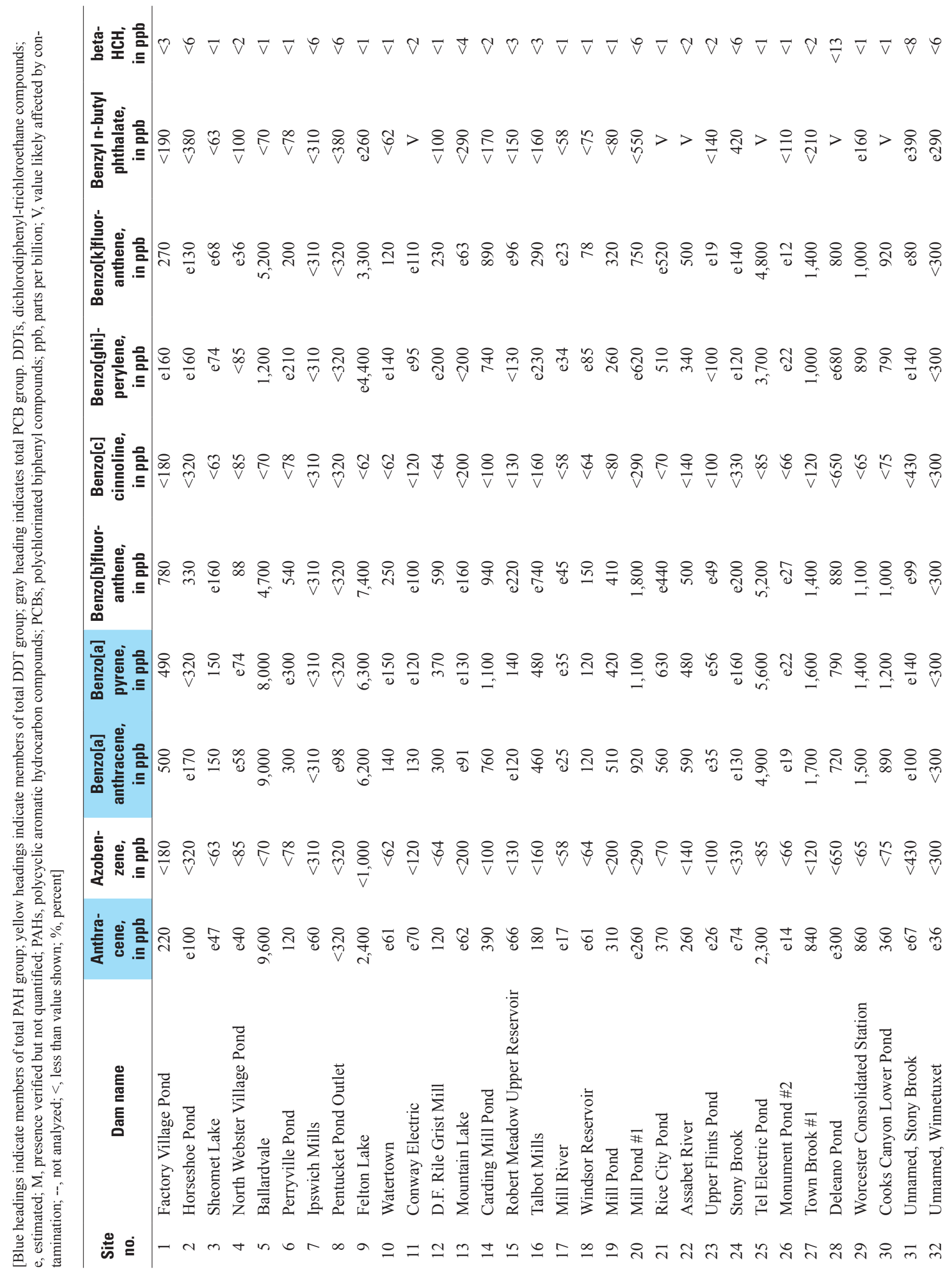




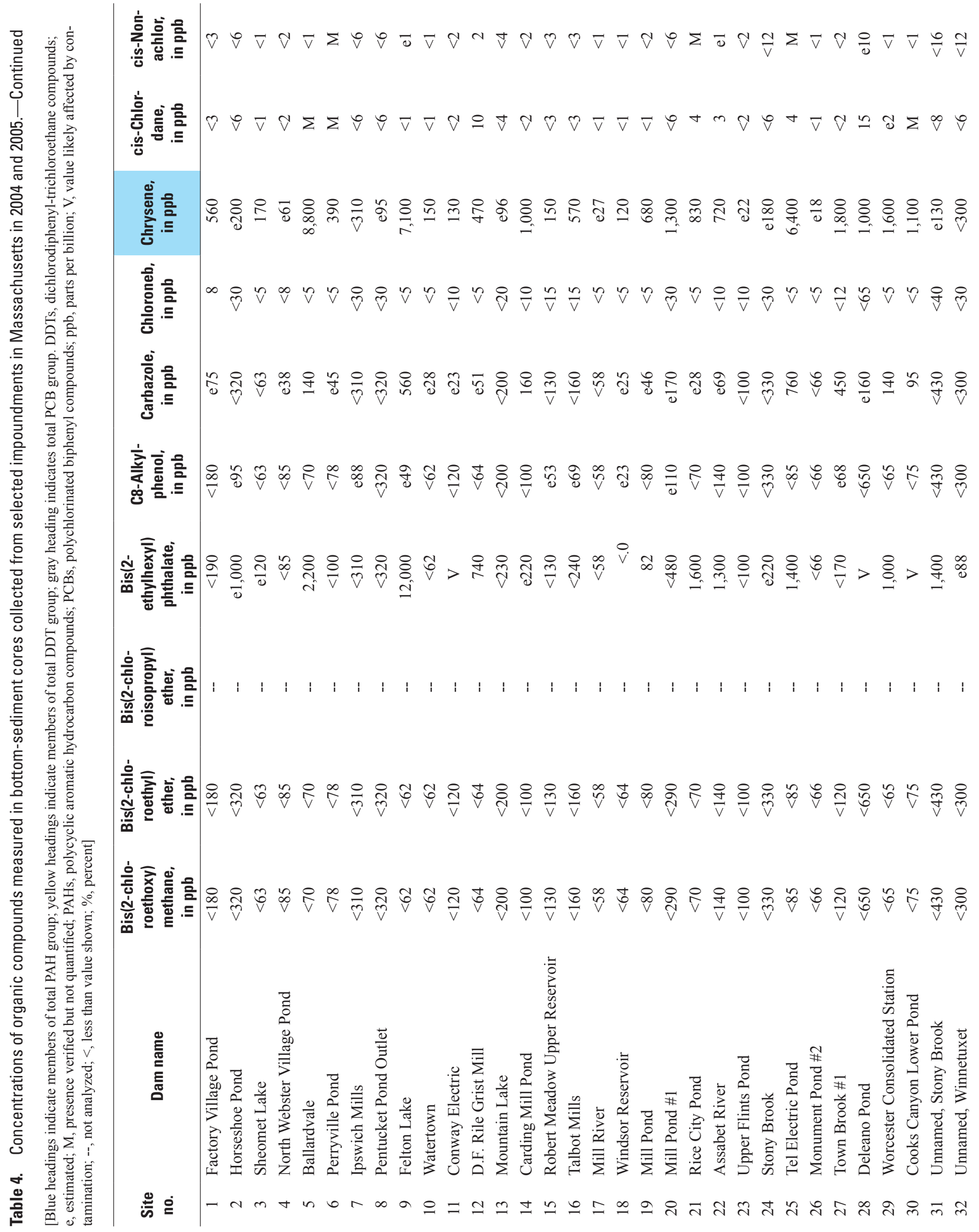




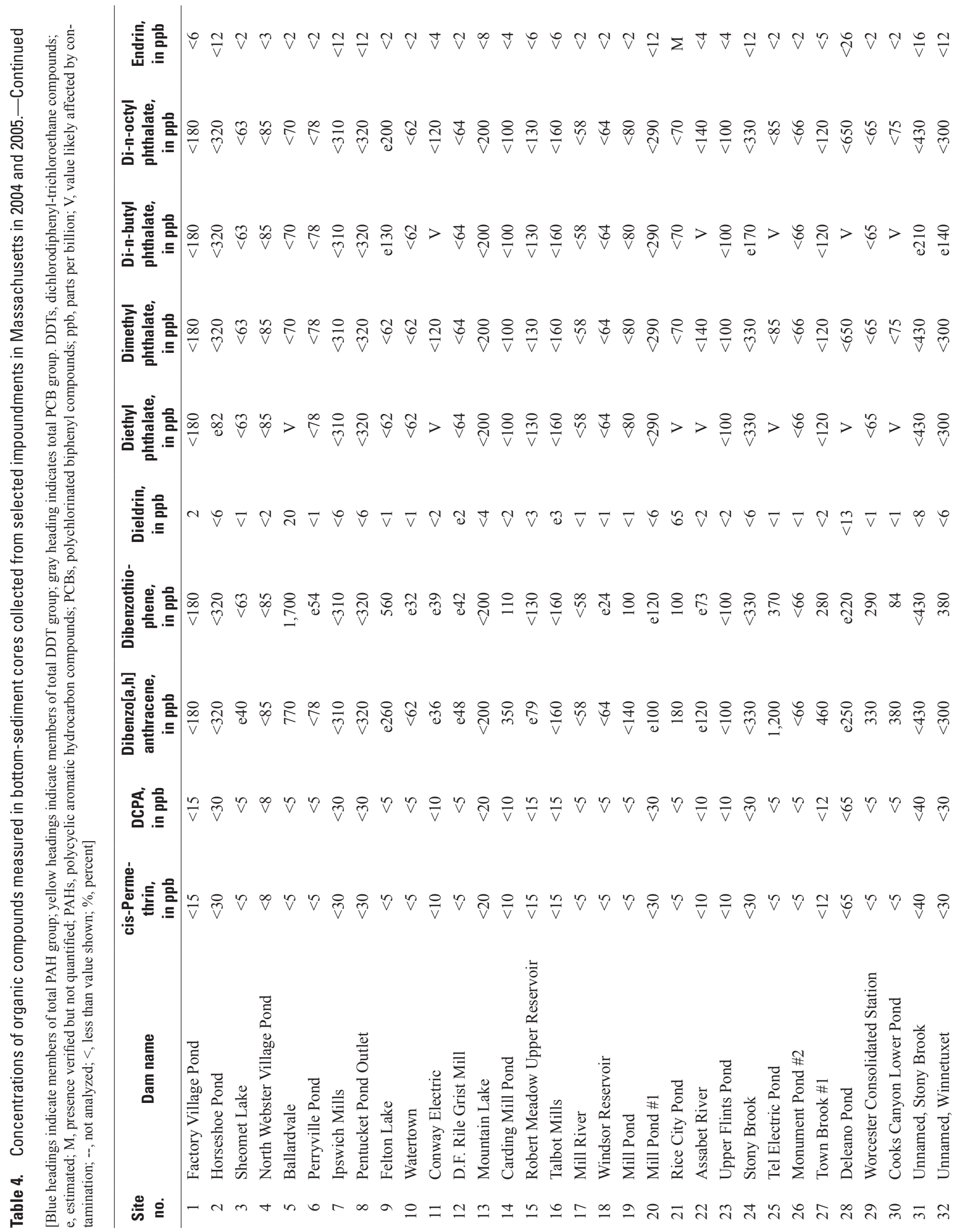




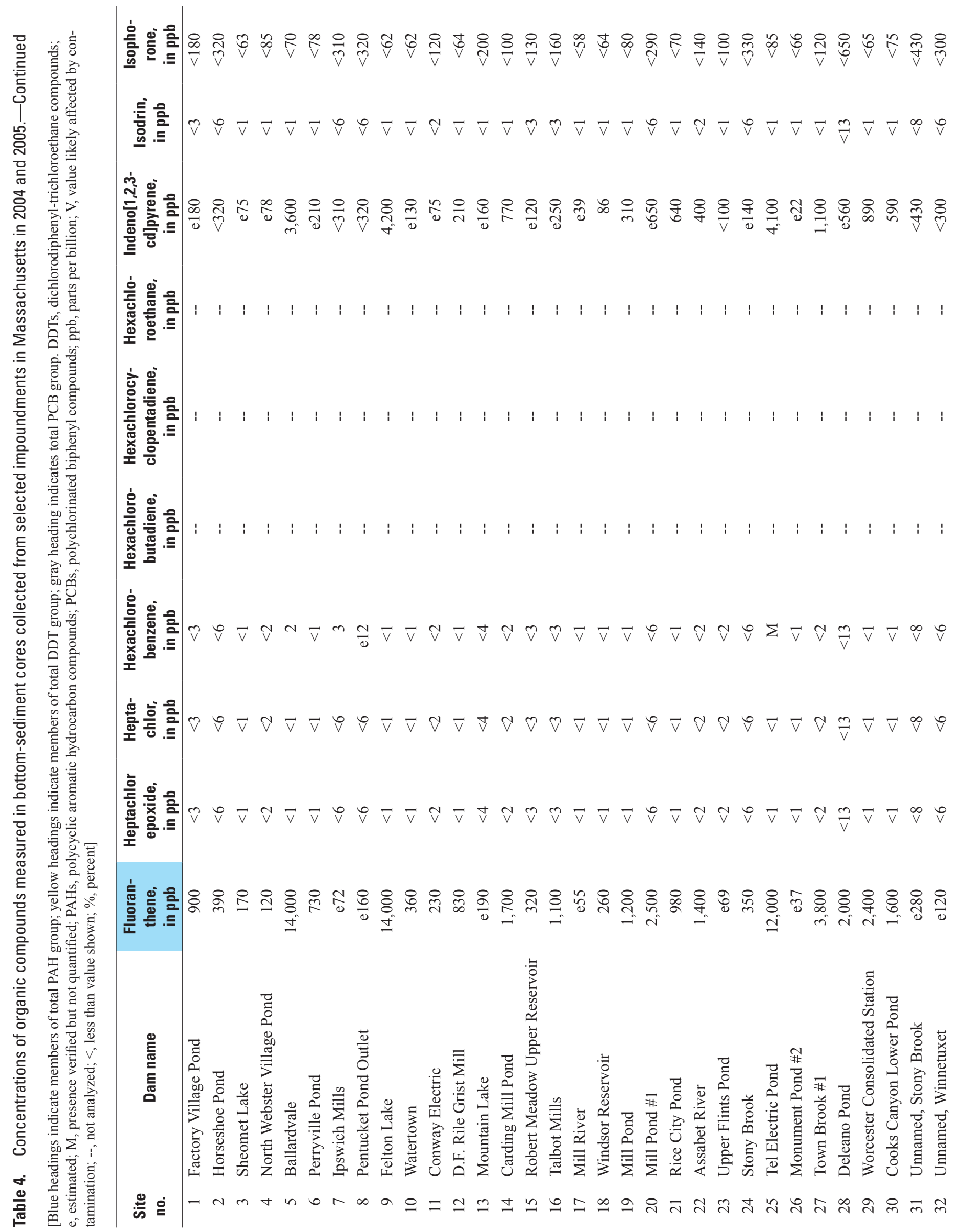




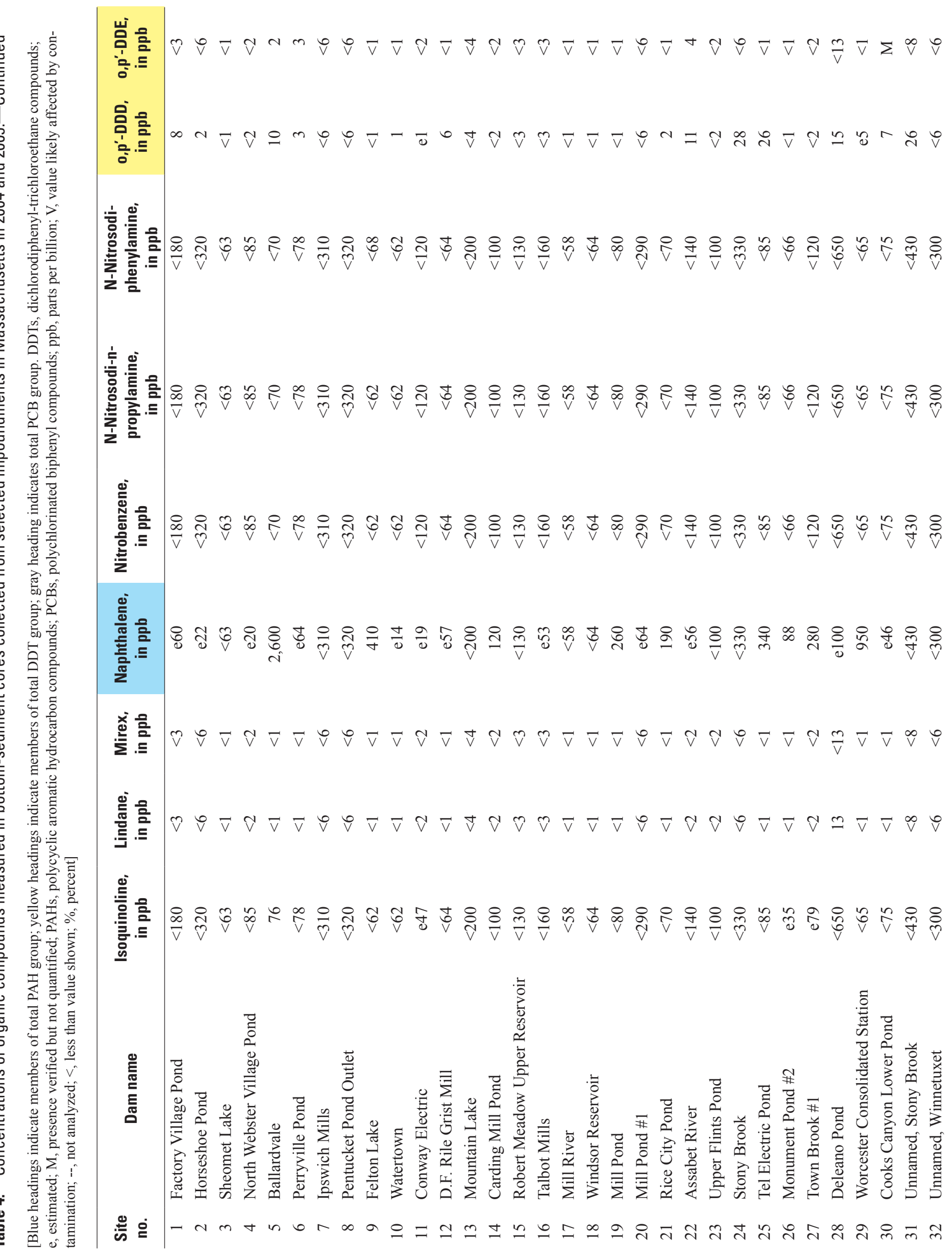




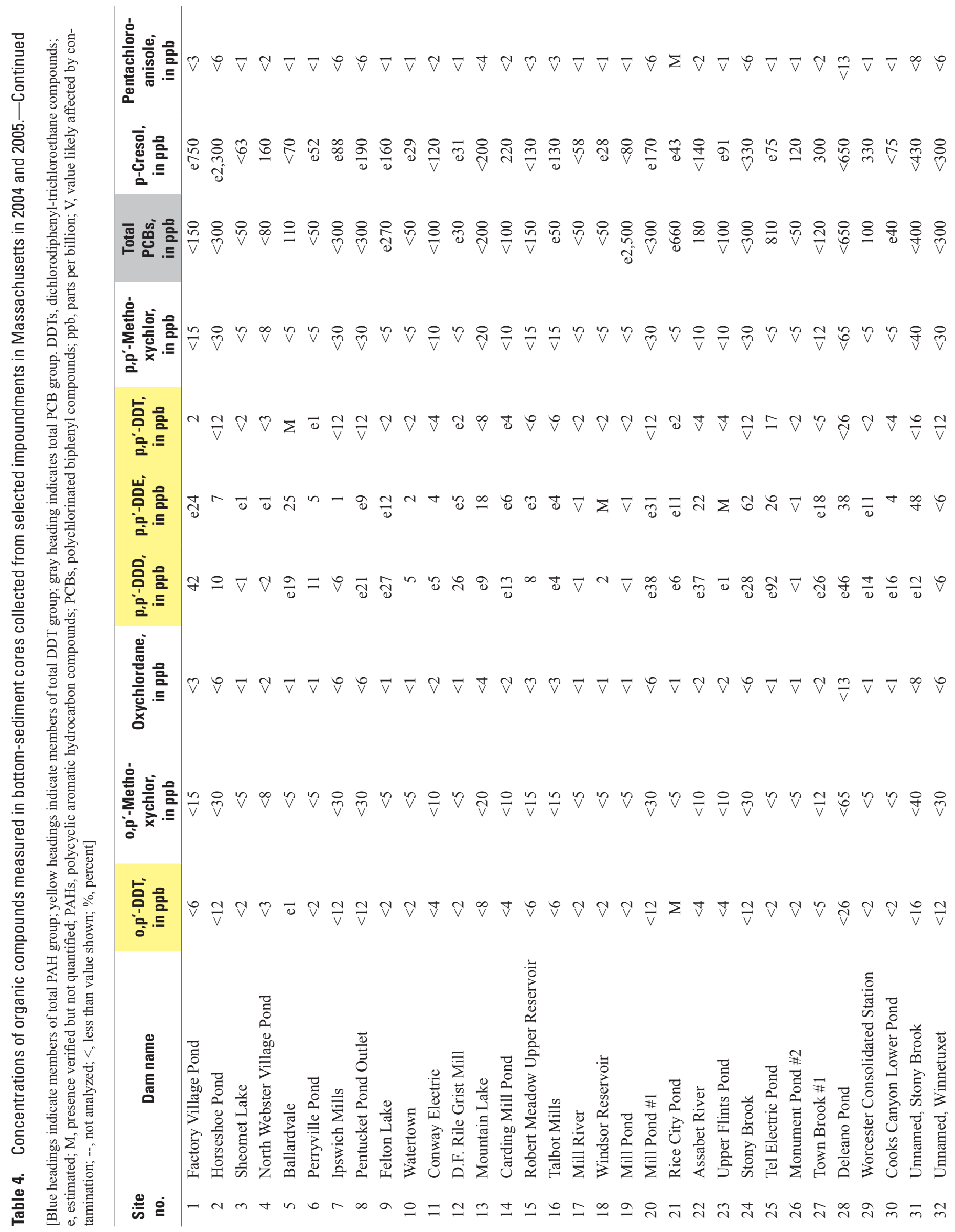


Table $4 \quad 41$

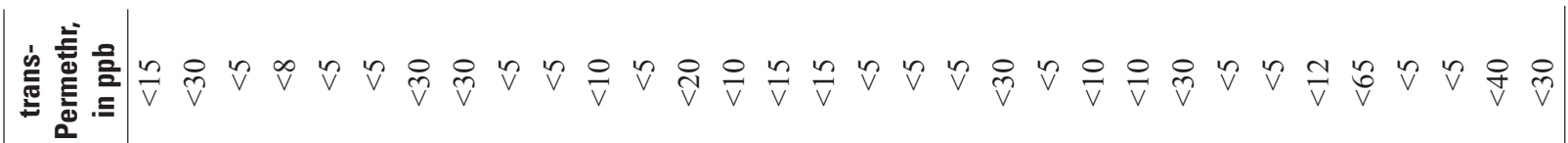

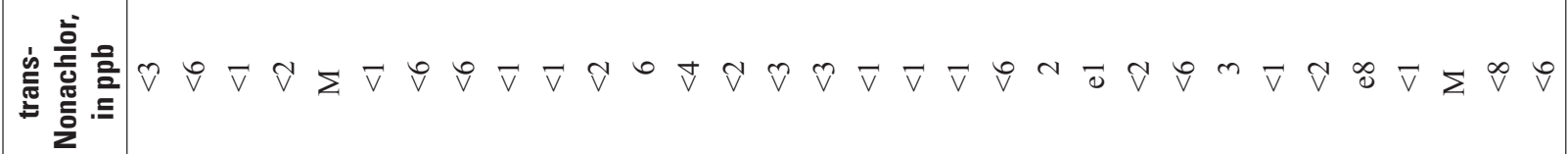

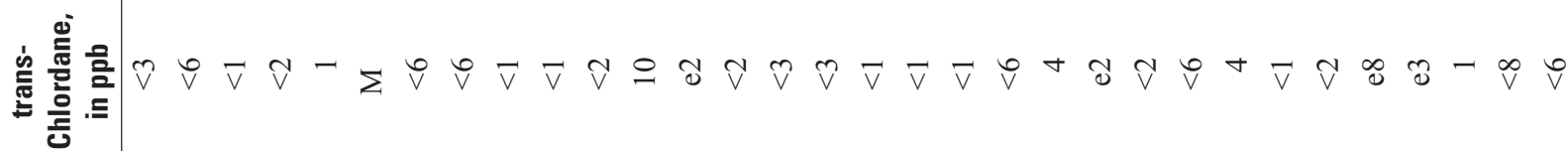

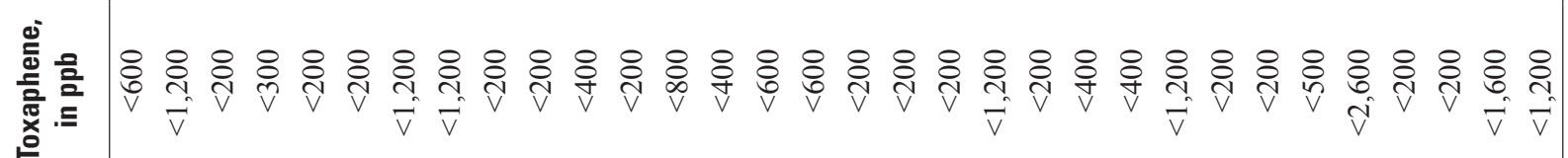

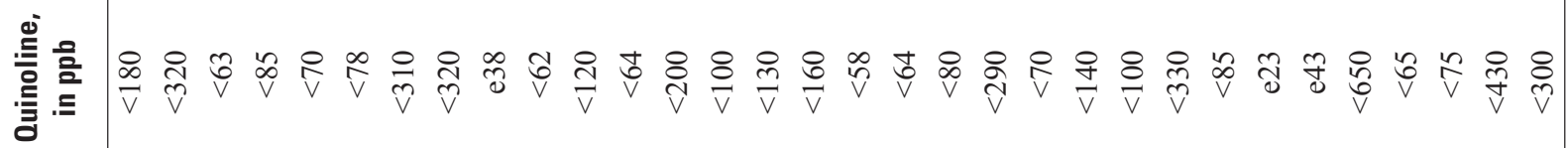
迹立

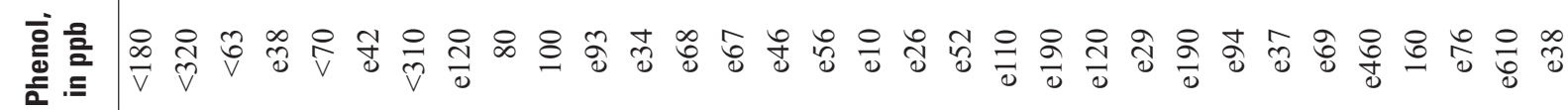

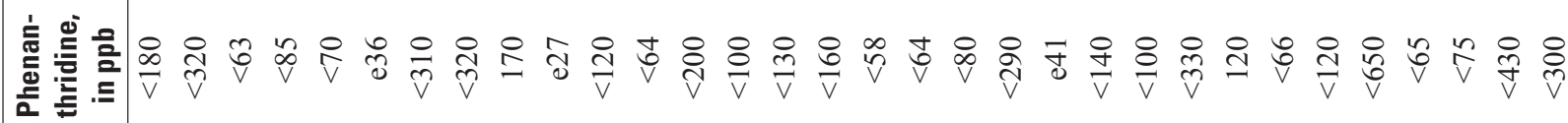

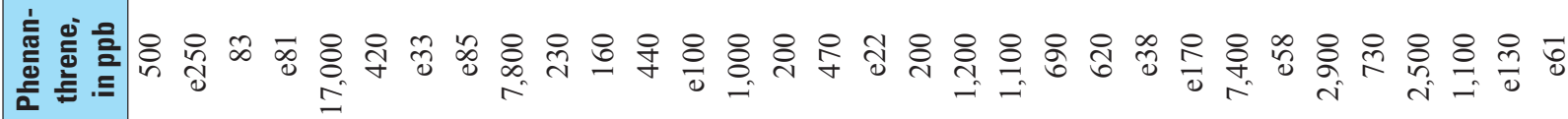
음

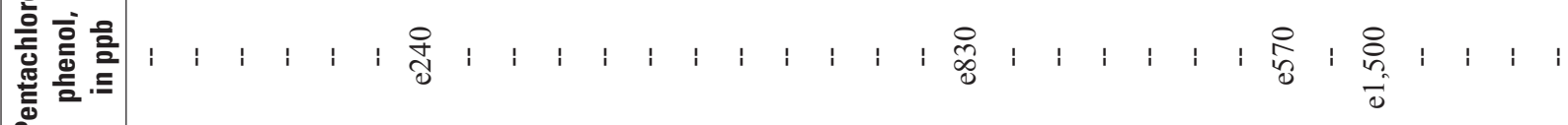
을 焉

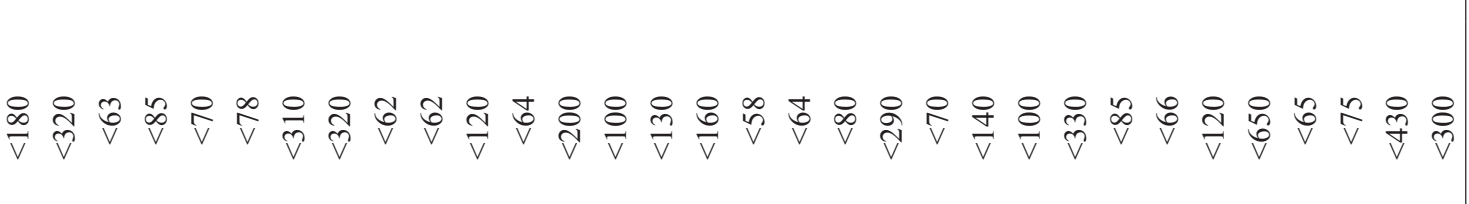
产 
THIS PAGE INTENTIONALLY LEFT BLANK 
Prepared by the Pembroke Publishing Service Center. For more information concerning this report, contact:

\section{Office Chief}

U.S. Geological Survey New England Water Science Center Massachusetts-Rhode Island Office 10 Bearfoot Road

Northborough, MA 01532

dc_ma@usgs.gov

or visit our Web site at: http://ma.water.usgs.gov 
